\title{
A Single-Cell Analysis of Early Retinal Ganglion Cell Differentiation in Xenopus: From Soma to Axon Tip
}

\author{
Christine E. Holt \\ Department of Biology, University of California, San Diego, La Jolla, California 92093
}

Intracellular injections of Lucifer yellow (LY) were made into the cell bodies of Xenopus retinal ganglion cells from the earliest stages of axonogenesis to the beginning of target innervation. Embryos were intact during the injection so that the entire cell (cell body, dendrites, axon, and growth cone) could be visualized. The purpose of the study was 3-fold: (1) to characterize the early steps in retinal ganglion cell differentiation before the axon reaches its target; (2) to determine whether guidepost cells exist as possible navigation cues in the vertebrate optic pathway; and (3) to investigate whether the morphology of early retinal ganglion cell growth cones varies in a position-dependent manner along the primordial optic pathway.

Axons were generally initiated before dendrites and followed a well-defined course along the primordial optic pathway without branching. Surprisingly, at least $5 \%$ of the retinal ganglion cells sent more than one axon into the optic pathway. Sister axons from the same parent cell traveled separately in the pathway, indicating that their growth cones navigated independently.

Examination of dendrite genesis showed that dendrites usually begin to emerge from the cell body well before the axon tip reaches the target. This observation argues against the possibility that target contact influences dendrite initiation. Nascent dendrites were commonly tipped with pronounced varicosities that did not resemble axon growth cones. Their number and branching correlated well with axon length, indicating that the age of the retinal ganglion cell itself, rather than the age of its presynaptic cells or local environment, is the strongest influence on dendrite genesis.

Examination of LY-filled growth cones at varying points in the pathway showed no evidence of dye transfer to adjacent cells. This indicates that gap junctional contacts probably do not form during axonal pathfinding and suggests that direct intercellular communication between growing axons and other cells in the pathway does not play a major role in axon guidance.

Growth cone morphology was analyzed quantitatively and

Received Dec. 19, 1988; revised Feb. 27, 1989. accepted Mar. 2, 1989.

I thank Bill Harris for his valuable discussions and comments, and also thank Bill Kristan, Don Sakaguchi, and Volker Hartenstein for their comments on the manuscript. I am indebted to Friederick Bonhoeffer for providing the facilities where much of this work was done. I thank Corey Goodman for his gift of Lucifer yellow antibody, and Peter Hausen's and Nick Spitzer's laboratories for providing Xenopus embryos. Lance Washington and Gisella Bauer provided technical assistance. This work was supported by the NIH (NS23780-02), the Alexander von Humboldt Foundation, and the McKnight Foundation.

Correspondence should be addressed to Christine E. Holt, Department of Biology, B-022, University of California, San Diego, La Jolla, CA 92093.

Copyright (C) 1989 Society for Neuroscience $0270-6474 / 89 / 093123-23 \$ 02.00 / 0$ found to vary at different positions along the pathway. Growth cones entering the optic nerve head were the largest and most complex; those on the retinal surface were the smallest and showed a simple morphology. Growth cones in the chiasm and optic tract showed a degree of complexity similar to those in the optic nerve head but were smaller. These findings suggest that new growth substrates are encountered at the optic nerve head where axons make approximately $45^{\circ}$ turns and support the notion that changes in growth cone morphology correspond with alterations in local microterrain along the pathway.

The morphological transformation of a nascent neuron into a mature one involves dynamic processes such as growth cone initiation, axon elongation, dendrite elaboration, axonal arbor formation, and synaptogenesis. Classical Golgi methods and single-cell dye injection techniques have been used to visualize some of the steps involved in this transformation. In invertebrates, for example, much has been learned about the pathfinding behavior of growing axons and the rearrangement of dendrites from examining the dye-filled processes of neurons injected with intracellular dyes (Goodman et al., 1981; Bentley and Keshishian, 1982; Taghert et al., 1982; Levine and Truman, 1985; Jellies et al., 1987). Similar intracellular techniques have now successfully been employed in vertebrate embryos and have yielded important information on the development of identified motoneurons (Eisen et al., 1986) and spinal neurons (Kuwada, 1986) and on the maturation of different classes of retinal ganglion cells (Sakaguchi et al., 1984; Dann et al., 1987; Ramoa et al., 1987). In the present study, Lucifer yellow (LY) was injected into single ganglion cells in the retina during early stages of their differentiation. The embryo and thus the whole of the CNS was intact during the injection, which enabled the ganglion cell body and its entire axon to be visualized. Such an approach differs from previous studies of the vertebrate CNS in that it allows a single cell from its soma to tip to be traced and has thereby enabled certain previously unresolved questions to be addressed at a single-cell level.

One question that motivated this study was whether the growth cones of retinal ganglion cells form dye-coupling junctions with other cells en route to their targets. Pioncer ncurons in the grasshopper nervous system have been found to contact and become selectively dye-coupled to specific cells in the pathway (Bentley and Keshishian, 1982; Taghert et al., 1982). These cells, known as landmark or guidepost cells, are often positioned at points in the pathway where axons make sharp turns, and it has been proposed that pioneer axons use chains of these cells to navigate to their largets, thus laying down the scaffold on which the mature nervous system is subsequently built (Bate, 1976; 
Bently and Keshishian, 1982; Taghert et al., 1982). Indeed, elimination of some of these cells causes a misrouting of pioneer and subsequent follower axons (Bentley and Caudy, 1983). Gap junctions mediate the intercellular transfer of LY (MW 457), and, while it is likely that major guidance cues are present on the surface of guidepost cells, it is also possible that small molecules passing between the growth cone and the guidepost cell soma play a role in signaling position and thus in orienting the direction of axon growth. The occurrence of gap junctions and electrical coupling is widespread between cells of developing tissues in embryogenesis (Furshpan and Potter, 1968; Blackshaw and Warner, 1976; Goodman and Spitzer, 1979; Guthrie, 1984) and is usually of a specific and transient nature (Lo Presti et al., 1974). In the vertebrate and invertebrate CNS, specific patterns of coupling between neuroepithelial cells often persist until the onset of neuronal differentiation and then disappear (Dixon and Cronly-Dillon, 1972; Hayes, 1976; Goodman and Spitzer, 1979; Sakaguchi et al,, 1984), suggesting the possibility that communication between neighboring cell interiors is important in developmental decisions. Indeed, blockage of junctional communication between cells in early Xenopus embryos using antibodies to gap junction proteins leads to major abnormalities in the CNS (Warner et al., 1984). It is unknown whether "secondary" coupling between extending axons and adjacent cells in their paths of the type described in the grasshopper nervous system exists in the developing vertebrate CNS. This paper specifically addresses this issue.

Growth cones are dynamic structures capable of changing their form in response to local cues in their environment. In vitro they change their morphology depending on the biochemical and physical nature of their surroundings (Harrison, 1914; Weiss, 1945; Letourneau, 1982), their rate of growth (Argiro et al., 1984), and contact interactions with other cells (Kapfhammer and Raper, 1987). In vivo growth cones tend to become larger and more complex at points in the pathway where divergent choices are made (Raper et al., 1983; Tosney and Landmesser, 1985; Caudy and Bentley, 1986a; Bovolenta and Mason, 1987). Conversely, growth cones tend to display simple morphologies in regions lacking obvious turning points (Tosney and Landmesser, 1985; Caudy and Bentley, 1986a; Bovolenta and Mason, 1987). In the embryonic visual system, the growth cones of early differentiating retinal ganglion cells traverse a variety of terrains as they journey along the primordial optic pathway to their primary central target, the optic tectum. In addition, major fiber reorganizations are known to occur in adult Xenopus in 3 separate regions of the optic pathway - the optic nerve, the brain entry point, and the chiasm (Fawcett et al., 1984; Taylor, 1987). Thus, it would be interesting to know whether the growth cones of early axons show any distinct changes in morphology in these fiber "resorting" regions. The present study addresses these issues by making quantitative comparisons of growth cones in all regions of the pathway.

In the vertebrate visual system, retinal ganglion cells have been observed to begin to elaborate dendrites at about the time their axons begin to innervate their central targets (chick: Rager, 1980; Xenopus: Sakaguchi et al., 1984; rat and cat: Maslim et al., 1986; cat: Ramoa et al., 1988). This temporal correlation suggests the possibility that target contact might be important for the initiation of dendrites. Trophic interactions are known to regulate dendritic arbor size and form in the peripheral nervous system (for review, see Purves et al., 1988), and so one might envisage that trophic factors picked up by the tips of retinal axons from the target tissue could influence ganglion cell differentiation. Another possibility might be that when the growth cones reach a particular point in the pathway they signal the cell to initiate dendrite formation. The present study examines the relationship between axonal outgrowth and dendrite initiation in single cells.

In this paper, I present evidence that addresses each of the above issues, namely, navigational growth cone dye coupling, growth cone morphology along the pathway, and dendrite genesis. In addition, some new features of ganglion cell morphogenesis will be described. An abstract of the work has previously been published (Holt, 1988).

\section{Materials and Methods}

Animals. Embryos were obtained by induced spawnings of adult Xenopus laevis or by in vitro fertilization of eggs from hormone-treated females. Fmbryos were raised in 10\% modified Ringer's solution (MR; Gimlich and Gerhart, 1984) or 10\% modified Barth saline (MBS; Gurdon, 1977) at 3 different temperatures, 23,20 , and $14^{\circ} \mathrm{C}$, which allowed a range of ages to be obtained from a single spawning. Embryo disscctions and intracellular injections were done in $100 \%$ MR or in MBS.

Preparation. Embryos from stages 28-41 (staging according to Nieuwkoop and Faber, 1956) were immobilized by spinal cord section or anesthesia ( $0.01 \%$ MS222; Sandoz) and pinned on their left sides in a Sylgard-bottomed petri dish. The skin overlying the eye, together with the lens rudiment were removed using sharpened minutien pins. This exposes the vitreal surface of the retina, giving immediate access to the retinal ganglion cell layer. Retinal ganglion cell axons begin to develop at stage 28 and reach the tectal primordium around stage 37/38 (Cima and Grant, 1980; Holt and Harris, 1983; Holt, 1984).

The preparation was viewed at high power $(144 \times)$ through a dissecting microscope and illuminated from the side in such a way as to give Nomarski-like optics in which the contours of the cell bodies could be distinguished at high magnification. This set-up allowed an almost vertical approach of the electrode into the retina, which was found to give better penetrations than an oblique one.

Intracellular $L Y$ injections. Live embryos were used for intracellular LY injection in the majority of cases. In some cases (approximately $20 \%$ ), embryos were fixed in $2 \%$ paraformaldehyde in $0.1 \mathrm{M}$ phosphate buffer for $5 \mathrm{~min}$ to $2 \mathrm{hr}$ prior to injection. Microelectrodes $(1 \mathrm{~mm}$ external diameter, 0.5 or $0.72 \mathrm{~mm}$ internal diameter glass) were pulled on a Brown and Flaming electrode puller and back-filled with $10 \%$ LY $\mathrm{CH}$ (Sigma) in $0.1 \mathrm{M} \mathrm{LiCl}$ (Stewart, 1978). These typically had resistances of 150-300 M $\Omega$. The microelectrode tip was positioned over the desired place in the retina, and cell penetrations were monitored using standard electrophysiological procedures. Impalements were accompanied by a -5 to $-40 \mathrm{mV}$ drop in potential, after which hyperpolarizing current pulses $(10 \mathrm{msec}$ duration, $20 \mathrm{~Hz})$ were used to eject the dyc (2-10 $\mathrm{nA}$ for $1-10 \mathrm{sec}$ ). Immediately after injection, the preparation was usually examined very briefly in a compound microscope using a LY fluorescence filter (Zeiss filter set 4877 09) with a $6.3 \times$ objective (to check for the presence of labeled cells) and then fixed by immersion in $4 \%$ paraformaldehyde in $0.1 \mathrm{M}$ phosphate buffer $(\mathrm{pH} 7.4)$ at $4^{\circ} \mathrm{C}$ after a variable time depending on the experiment. After fixation (2-24 hr) the injected eyes were examined with LY fluorescence using a $40 \times$ waterimmersion objective, and selected cases were photographed.

Antibody staining. In this study it was necessary to use a dye sensitive enough to label fine cellular processes and one small enough to pass through gap junctions: LY meets these requirements. However, it has several limitations such as (1) the presence of a strong halo around the injected cell body that obscures fine detail close to the soma; (2) fine structures such as filopodia extending from growth cones are bleached rapidly under fluorescent illumination and so are lost; and (3) the light fixation in paraformaldehyde required to maintain low background fluorescence does not maintain tissue integrity through sectioning. Therefore, to obtain permanent high-quality records of LY-filled cells, injections were followed by HRP immunohistochemistry using a serum antibody to LY (Taghert et al., 1982) and by postfixation in glutaraldehyde.

The skin along with the uninjected left eye was removed, and the brain with the injected eye attached was dissected free from the embryo. These brains with attached right eyes were then immunolabeled with 

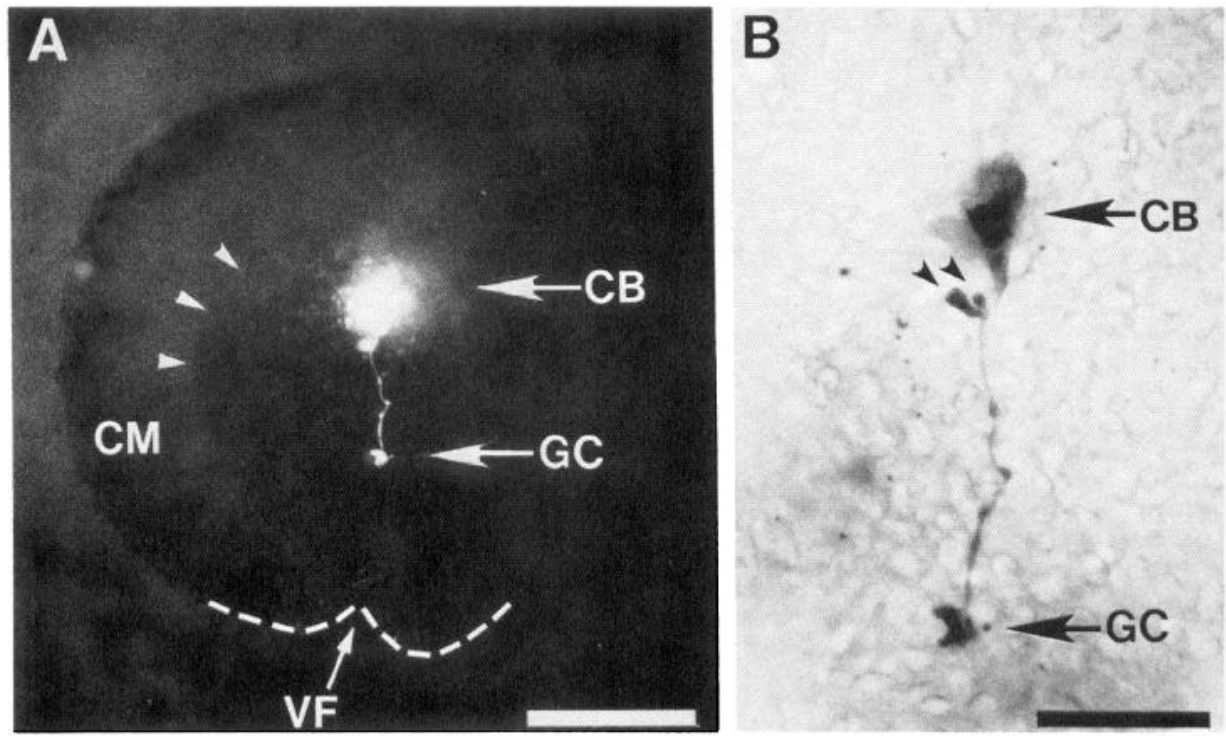

Figure 1. LY-filled retinal ganglion cell shown in a whole-mount preparation of a stage 28 retina $(A)$ and after immunolabeling with anti-LY and HRP $(B)$. Axonogenesis has just begun so this labeled axon is one of the first to navigate across the retina. In $A$, the axon and growth cone ( $G C$ ) are clearly labeled; the fine structural details such as the varicosities on the axon and the morphology of the growth cone are preserved following immunolabeling $(B)$. In $A$, however, the intensity of fluorescence at the cell body $(C B)$ obscures the outline of the perikaryon together with the structural details in the initial segment of the axon. By contrast, in $B$ the outline of the perikaryon can be seen clearly together with 2 small branches extending from the axon close to the cell body (small arrowheads). The arrowheads in $A$ indicate the inner border of the ciliary margin ( $C M$ ); the dashed lines indicate the outline of the ventral lobes of the eye which are separated by the cleft of the ventral choroidal fissure (VF). Dorsal is $u p$. Scale bars: $A, 50 \mu \mathrm{m} ; B, 20 \mu \mathrm{m}$.

anti-LY antibody $(\alpha$-LY) as whole-mounts. They were incubated in $\alpha$-LY for $40-60 \mathrm{~min}$ at $32^{\circ} \mathrm{C}$, and a Vectastain $\mathrm{ABC}$ kit was used to label this antibody with peroxidase. Following this, the samples were reacted in $0.1 \%$ diaminobenzidine (DAB; Sigma), postfixed for $1 \mathrm{hr}$ in $2 \%$ glutaraldehyde, embedded in gelatin/albumin, and then cut at 40 $\mu \mathrm{m}$ on an Oxford vibratome.

Intracellular HRP fills. Intracellular techniques similar to those described for LY were used to fill retinal ganglion cells with HRP (see Holt et al., 1988). A solution of $2 \% \mathrm{HRP}$ (Sigma Type IX) in $0.2 \mathrm{M} \mathrm{KCl}$ was used to backfill the electrodes, which were made from either triangular glass or standard $0.72 \mathrm{~mm}$ i.d., $1.0 \mathrm{~mm}$ o.d. glass. These had resistances of around $200 \mathrm{M} \Omega$. After penetrating a cell, pressure was used to eject the dye. In some instances, current pulses alone were used. In general, it was found that pressure-filled cells were more darkly stained than current-injected ones, indicating that more HRP was ejected from the microelectrode using pressure. Samples were fixed in $1.5 \%$ glutaraldehyde $/ 2.5 \%$ paraformaldehyde in $0.1 \mathrm{M}$ phosphate buffer for $1-2 \mathrm{hr}$ at $4^{\circ} \mathrm{C}$ from 3-15 min following injection. Whole-mount brains with the injected eye attached were reacted with $0.1 \%$ DAB for $1 \mathrm{hr}$ and sectioned on a vibratome at $40 \mu \mathrm{m}$.

HRP fills of the leading growth cones for electron microscopy. In order to label the leading growth cones the whole population of retinal ganglion cells was filled by extracellular application of HRP to the whole eye cup at different stages of development using methods previously described (Harris et al., 1985; Harris, 1986). Whole brains were reacted for HRP (see above), and those to be processed for electron microscopy were postfixed in $1 \%$ osmium tetroxide for $1 \mathrm{hr}$, embedded in gelatin/albumin, and sectioned at $40 \mu \mathrm{m}$. Sections were examined in the light microscope, and those that showed clear leading growth cones were drawn at $1750 \times$ magnification using a camera lucida attachment. Selected sections were embedded in Epon between 2 sheets of acetate and sectioned at $5 \mu \mathrm{m}$. The sections containing the growth cone of interest (previously identified in the $40 \mu \mathrm{m}$ section) were ultrathin sectioned, stained with uranyl acetate and lead citrate, and examined in the electron microscope (Phillips 200).

Quantitation of growth cones and dendrites. The profiles of 164 growth cones were drawn at $1750 \times$ magnification with camera lucida using Nomarski optics on a Zeiss photomicroscope. Measurements were made directly from the drawings. In measuring the total length, the beginning of the growth cone was usually defined by a fairly abrupt thickening of the axon. However, in some cases where the growth cone expanded gradually or where there was little increase in the overall width at the tip, the beginning of the growth cone was taken to be the point that was half the distance between the growth cone's fullest width and the axon's width. The width of a growth cone often varied substantially along its length, so 4-6 measurements were made across the body of each growth cone at equal intervals and the mean width was then calculated.

Thin processes $(0.2-0.5 \mu \mathrm{m})$ that projected $2 \mu \mathrm{m}$ or more from the growth cone core were classed as filopodia. These structures ranged from 2 to $15 \mu \mathrm{m}$ in length and were not included in the size measurements of the growth cone. To obtain a measure of complexity, all of the filopodia extending from each growth cone were counted. Processes shorter than $2 \mu \mathrm{m}$ were not included in the analysis. Lamellopodia, thin, veil-like extensions, were also present on some growth cones but occurred at a fairly low frequency (approximately $20 \%$ of growth cones) compared with filopodial extensions. These were classified as single processes in the quantitation.

Statistical analysis of dendrite formation was done on 188 cells in which the position of the growth cone emanating from identified cells in the retina could be located in the pathway. Primary dendrites (those emitted directly from the cell body), and not secondary or tertiary dendrites (those resulting from branching of primary dendrites), were counted to quantitate the number of dendrites per cell. Dendrites exhibiting a single branch point or more were classified as branched dendrites. Multiple regression and correlation analyses were done using the RS1 statistical software package on an IBM computer.

\section{Results}

In this study, a total of 799 intracellular injections were made (671 LY, 128 HRP). These yielded 770 labeled cells (666 LY, 104 HRP). Approximately $20 \%$ of the retinas received injections at a single site. The rest received $2-5$ penetrations each (30-50 $\mu \mathrm{m}$ apart). Approximately $50 \%$ of labeled cells did not possess axons or processes. These were identified as either neuroepithelial or Müller cells. Those that were in the retinal ganglion cell layer and possessed an axon traveling on the vitreal surface were identified as ganglion cells.

The cell bodies of retinal ganglion cells injected with LY were 


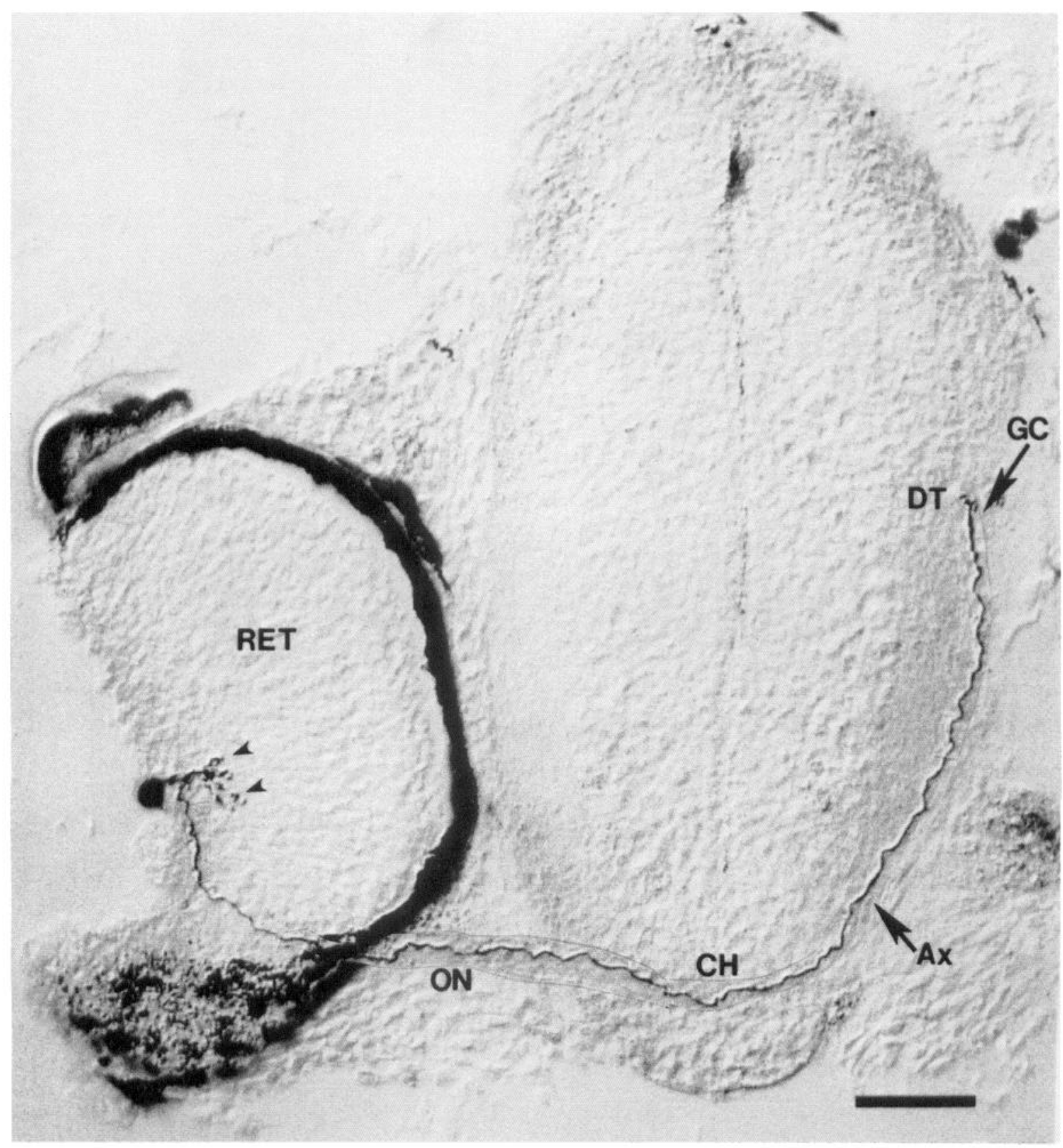

Figure 2. A single retinal ganglion cell filled with LY and immunolabeled with HRP. Composite photograph of two $40 \mu \mathrm{m}$ transverse sections at 4 different focal planes. The cell body possesses numerous dendrites (arrowheads) and its axon $(A x)$ can be seen coursing through the optic nerve $(O N)$, chiasm $(C H)$, and optic tract and its growth cone $(G C)$ in the dorsal optic tract $(D T)$. The embryo was at stage $37 / 38$, the time at which the very first visual axons reach the optic tectum, some $50-100 \mu \mathrm{m}$ ahead of this growth cone. The black pigment around the retina (RET) is the pigmented epithelium. Note that the axon comes off the primary dendrite shaft. Also, note the terminal varicosities of the dendrites. Dorsal is $u p$. Scale bar, $50 \mu \mathrm{m}$.

strongly fluorescent, and their axons could be seen exiting the retina or terminating in growth cones on the retinal surface in whole embryo preparations (Fig. 1A). HRP immunohistochemistry using the $\alpha$-LY antibody seemed to preserve, at the very least, the structural details of the axon and growth cone and to considerably enhance such details near the cell body. For example, Figure $1 A$ shows a bright halo of fluorescence around an injected retinal ganglion cell body, and Figure $1 B$ shows the same cell after immunolabeling with HRP. The shape of the cell body is clearly visible in the immunolabeled preparation, as are 2 short processes branching off the axon close to the soma (Fig. $1 B$ ). Neither of these, however, are clearly visible with fluorescence.

The dye spreads from the soma to the axon tip within 2-5 $\min$. Growth cones at the axon tip were well labeled and displayed fine filopodia. Two to six transverse sections $(40 \mu \mathrm{m})$ through the midbrain, diencephalon, and retina contained all the processes of any filled neuron (see Fig. 2). 


\section{Growth cones}

\section{Morphology of growth cones in the pathway}

The growth cones of retinal ganglion cells injected with LY exhibited a range of morphologies varying from simple clubshaped forms to complex stellate and filiform types. To investigate whether a correlation exists between the morphology of the growth cone and its position, the general morphology, size, and complexity of growth cones at 8 different points in the pathway were analyzed (see Fig. 3 ). These included the retinal surface $(n-22)$, the entry to the optic nerve head $(n=28)$, the optic nerve $(n=34)$, the brain entry point $(n=17)$, the chiasm $(n=21)$, the ventral optic tract $(n=29)$, and the mid and dorsal optic tract $(n=13)$. Within each of these regions a wide range of growth cone morphologies was observed. However, a predominant type of morphology could be identified as occurring in particular places in the pathway. On the retinal surface, for example, growth cones tended to be short and club-shaped, whereas they were filiform in the optic tract and elongated in the optic nerve (see Figs. 4 and 5). Backward-projecting filopodia were more common at the chiasm and the optic nerve head than elsewhere.

Quantitative analysis of the dimensions and complexity of growth cones corroborate these morphological classifications (Figs. 6 and 7). Growth cones at the entry to the optic nerve head are significantly longer than those at other places in the pathway (length $\sim 20 \mu \mathrm{m}$ ); those on the retinal surfacc and in the mid-dorsal optic tract tended to be the shortest (length $\sim 12$ $\mu \mathrm{m})$. The width of growth cones was fairly constant throughout the pathway $(2-2.5 \mu \mathrm{m})$ except at the optic nerve head, where growth cones were significantly wider than elsewhere (width $\sim 3$ $\mu \mathrm{m})$. From the optic nerve to the ventral optic tract, growth cone area did not change significantly. Growth cones on the retinal surface and in the oplic nerve had significantly fewer processes (1-2 filopodia; Fig. 7) than those in the optic nerve head (4-5 filopodia) and in the contralateral stretch of the pathway (4-5 filopodia). Thus, growth cones that are turning into the optic nerve head, after leaving the retinal surface, are not only the largest ones in the whole pathway but are also among the most complex. These growth cones also appear to possess comparatively long filopodia (up to $15 \mu \mathrm{m}$; see Figs. $4 B$ and 5).

I wondered whether the characteristically simple growth cones seen in the retina might be an artifact due to injury by the injection. In the retina, growth cones are closer to the cell body than elsewhere, so one might expect a retraction of filopodia, an injury response, to occur soon after injection. Two lines of evidence argue against this possibility. (1) By the same line of reasoning one would expect the complexity of growth cones to

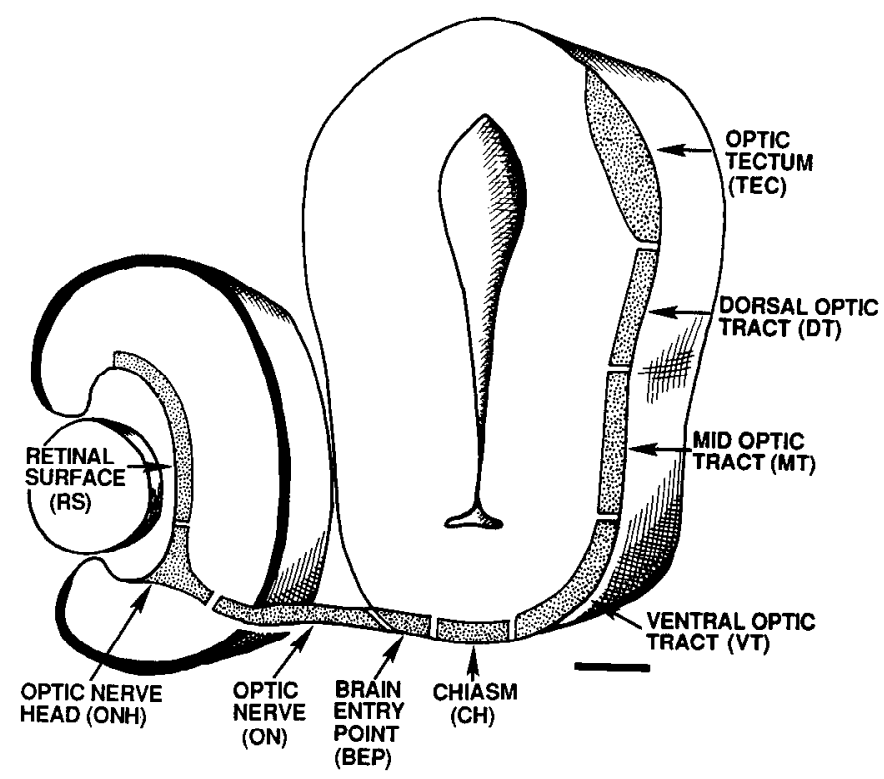

Figure 3. Schematic representation of the optic pathway (stippled region) in the embryo. The midbrain and retina are shown in transverse section. The optic pathway, which is continuous in vivo, is divided here into 9 separate regions (retinal surface through to optic tectum). Axon tips in each of these regions were analyzed. Dorsal is up. Scale bar, 50 $\mu \mathrm{m}$.

increase with distance from the cell body. This is not the case since growth cones in the optic nerve head are more complex than those in the optic nerve. (2) Samples that were fixed before injection ( $n=17)$ also had simple morphologies ( 1 or 0 filopodia) in the retina and were similar in size and appearance to the liveinjected samples at all points in the pathway.

\section{Followers versus pioneers}

Early-growing axons, because they are growing in territory virgin to optic axons, might show distinct, possibly more complex, morphologies than later growing axons. Early "pioneer" axons were identified as those that have reached a point in the pathway known from previous studies (see Holt and Harris, 1983; Holt, 1984) to be the furthest point for that particular stage. For example, at stage 32 , the lead fibers are usually seen at the chiasm. "Followers" were defined as those that trailed the expected position of the leading edge by some $30 \mu \mathrm{m}$ or more. A comparison between the pioneer and follower growth cones shows that these 2 populations are similarly complex throughout the pathway (Table 1). Simple growth cones were defined as having

Table 1. The complexity of pioneer versus follower growth cones

\begin{tabular}{lccccccc} 
Growth cone type & $\begin{array}{l}\text { Retinal } \\
\text { surface }\end{array}$ & $\begin{array}{l}\text { Optic } \\
\text { nerve } \\
\text { head }\end{array}$ & $\begin{array}{l}\text { Optic } \\
\text { nerve }\end{array}$ & $\begin{array}{l}\text { Brain } \\
\text { entry } \\
\text { point }\end{array}$ & Chiasm & $\begin{array}{l}\text { Optic } \\
\text { tract }\end{array}$ & $\begin{array}{l}\text { Percent- } \\
\text { age com- } \\
\text { plexity }\end{array}$ \\
\hline $\begin{array}{l}\text { Pioneer } \\
\quad \text { Simple }\end{array}$ & 2 & 0 & 1 & 0 & 1 & 3 & 19 \\
$\quad \begin{array}{l}\text { Complex } \\
\text { Follower }\end{array}$ & 1 & 2 & 3 & 1 & 0 & 23 & 79 \\
$\quad$ Simple & 25 & 2 & 12 & 4 & 6 & 1 & 35 \\
Complex & 6 & 13 & 18 & 12 & 18 & 27 & 65
\end{tabular}



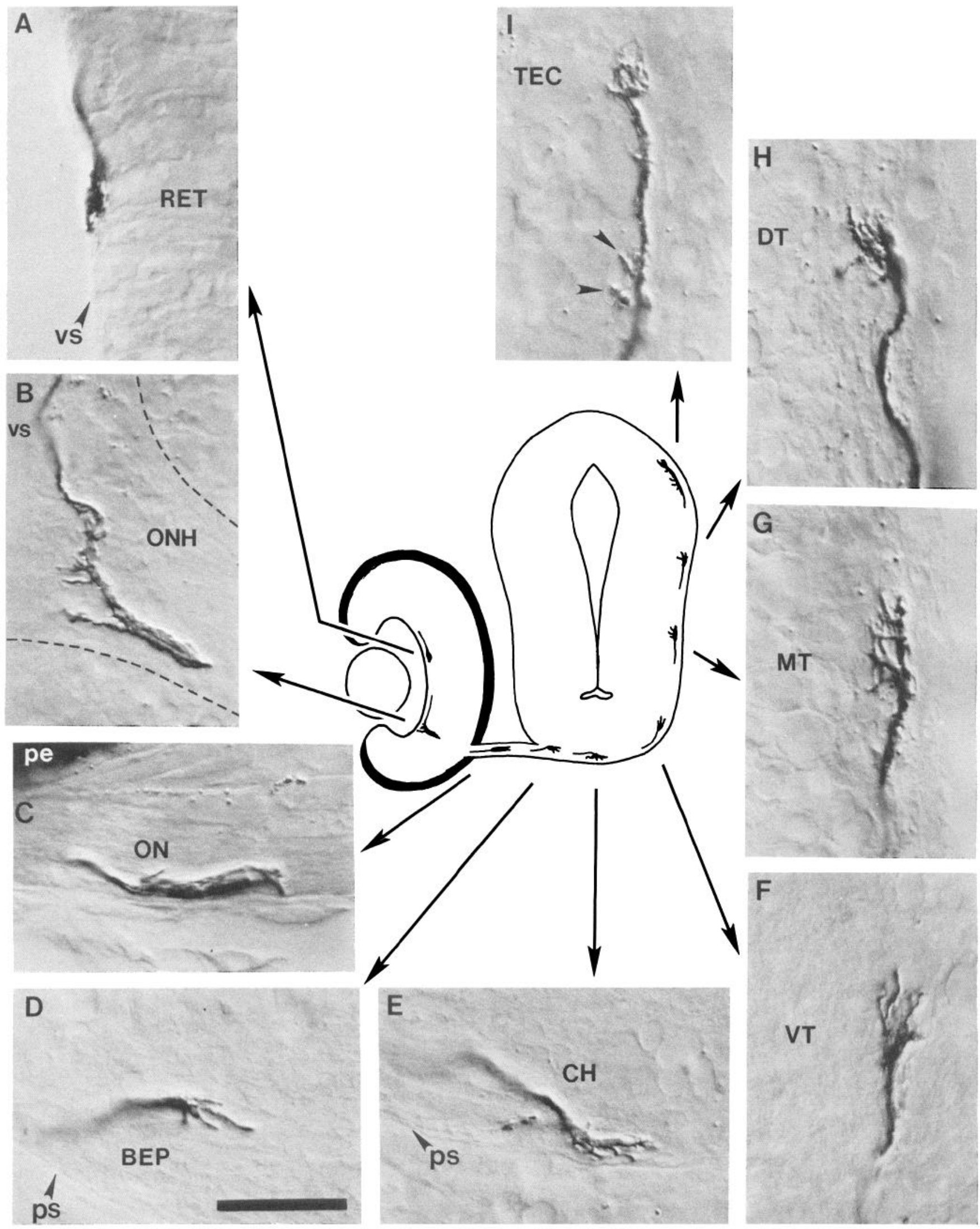

Figure 4. Light micrographs of growth cones in each region of the embryonic optic pathway showing their differing morphologies. The line drawing in the center represents the outline of the eye and brain in transverse section and shows the positions of the growth cones. In the retina $(A)$, a small, simple growth cone can be seen closely apposed to the vitreal surface $(V S)$; at the turn into the optic nerve head $(O N H)$ shown in $B$, a large, complex growth cone with several filopodia pointing toward the vitreal surface is shown. Dashed lines indicate the borders of the ONH. In the optic nerve $(O N ; C)$, a growth cone is shown with an elongated profile. Note that the width of the optic nerve is only about 2.5 times that of the width of the 
1 filopodium or less; complex ones as having 2 or more filopodia. Simple growth cones occur at a higher frequency in the follower population $(35 \%)$ than in the pioneer population $(19 \%)$. This difference is not significant since it can be seen to reflect the fact that more growth cones were sampled in the retina and in the optic nerve in the follower population than in the pioneer population (Table 1). As shown in Figure 7, these 2 places in the pathway characteristically harbor growth cones with simple profiles. Follower growth cones of retinula axons in the Daphnia eye fasciculate with the lead fibers and have simple clublike morphologies (Lo Presti et al., 1974). This does not seem to be the case here since follower fibers are mostly complex and do not appear to fasciculate with earlier fibers. Growth cones from retinal ganglion cells born at the ciliary margin during larval development were not examined in this study so it is not known whether "late followers" behave similarly to the embryonic "early followers" described here.

\section{Position of growth cones with respect to the pial surface}

It has been suggested that the basement membrane surrounding the CNS might contain molecular information necessary for fiber guidance (Sanes, 1983). Thus growth cones might be expected to be located closely apposed to the basement membrane or at least to maintain filopodial contact with it. At the light microscope level, the majority of growth cones in the optic tract were indeed located close (within $10 \mu \mathrm{m}$ ) to the pial surface (see Figs. 5; $11, G, H$ ). Electron microscopic analysis of HRP-filled growth cones in this region showed, however, that the main body of these growth cones and their filopodia were almost never directly apposed to the basement membrane. Only rarely was a labeled filopodium seen to be in direct contact with it (Fig. $8 B$ ). This was seen in 2 instances in 5 serially sectioned growth cones, each of which had numerous (5-6) filopodia. Instead, growth cone processes were separated from the basement membrane by the endfeet and radial processes of gliallike cells with which close contacts were often made (Fig. 8A). This observation is similar to findings in the embryonic mouse visual pathway where growth cones associate most commonly with neuroepithelial cell endfeet (Silver and Rutishauser, 1984).

In the retina, growth cones were mostly found closely apposed to the vitreal surface (see Fig. $4 A$ ). Occasionally, they were some distance away (up to about $15 \mu \mathrm{m}$ ); this was not commonexcept, of course, after they had entered the optic nerve head. Electron microscopy of the developing retina and optic nerve by Bork et al. (1987) has shown that growth cones contact the endfeet of neuroepithelial cells but not the basement membrane in these regions. This is also the case in the embryonic monkey (Williams and Rakic, 1985). In the head of the optic nerve and in the optic nerve proper (outside the retina) growth cones were situated at the edges (dorsal and ventral) and in the center with more or less equal frequencies. At these early stages of development, when the optic nerve contains approximately 1000 fibers (stage 40; Wilson, 1971) and has a diameter of only 10$15 \mu \mathrm{m}$, the growth cones are potentially capable of sampling a large fraction of the internal diameter of the optic nerve at any one time.

Even though the growth cones were usually close to the pial surface in the brain, the axons were very often some distance from it (Fig. $11 H$ ). In the optic tract the axons of retinal ganglion cells whose growth cones had arrived at the tectum were usually deep to the pial surface (15-20 $\mu \mathrm{m}$ away), close to the border between the central cell mass and the neuropil region. This suggests that newly grown axons are rapidly displaced from the surface by the growth cones of later growing axons.

\section{Dye coupling in the embryonic visual system}

Evidence against dye coupling between growth cones and adjacent cells

A question of special interest was whether the growth cones of early-differentiating retinal ganglion cells make dye-coupling junctions with cell bodies they pass in the pathway. Of all the LY-labeled growth cones that were examined in the retina, optic pathway, and tectum ( $n=245)$, no instance of dye transfer to cells in the immediate vicinity of labeled growth cones was found.

The possibility that the usual survival time postinjection of 2-5 min was too short to allow transfer of the dye was checked by using longer survival times (15-90 min). The growth cones in these cases appeared normal, showing complex morphologies in the optic tract; however, none of these long-term survivors $(n=7)$ showed any evidence of dye coupling. Dye spreads between coupled neuroepithelial cells in the undifferentiated retina or at the peripheral margin within 2 min and was frequently observed among the undifferentiated cells in the center and periphery of young retinae (stage 28 ) and around the ciliary margin in more mature retinae (stage $33 / 34$ onwards). The possibility that dye coupling was occurring but was simply not detectable because of insufficient dye molecules to pass into an "attached" cell is unlikely because growth cones were usually intensely labeled and, as mentioned above, dye coupling between cells in the retina was easily detectable.

Another possibility for not detecting dye transfer is that the anesthetic used in many of the experiments might block gap junctional communication. MS222, a tricainc-bascd ancsthetic, was used in the experiments, and tricaine has been found to block gap junctions in other systems (Spray et al., 1982). To circumvent this possible problem, intracellular fills were performed on embryos without anesthesia and which had been immobilized by cutting the spinal cord. This procedure was used approximately $50 \%$ of the time. Again, no growth cone-to-cell coupling was seen. Dye coupling between skin epithelial cells and between retinal neuroepithelial cells was seen frequently with anesthesia indicating that the gap junctions at least between these 2 types of cells were not blocked by MS222.

At an early stage of the study, several cases were classified as "peripheral coupling" where the growth cones of retinal ganglion cells in the peripheral retina appeared to be dye coupled to more centrally located cell bodies in the retina. These were seen some-

growth cone. At the brain entry point $(B E P ; D)$ and the chiasm $(C H ; E)$ growth cones have fingerlike filopodia that are often close to the pial

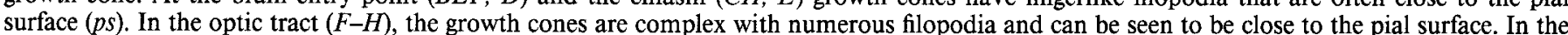

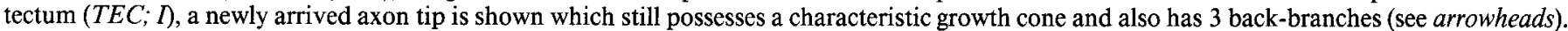

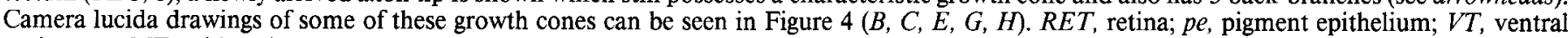
optic tract; $M T$, mid optic tract; $D T$, dorsal optic tract. Scale bar, $20 \mu \mathrm{m}$. 


$$
\begin{aligned}
& \text { 13\{4U19 - } \\
& \text { 19946) } \\
& \text { 1)191194 } \\
& \text { (1)? P) } 194= \\
& \text { S3Y)KMIY } \\
& 3149313\}= \\
& \text { 111949\}? }
\end{aligned}
$$



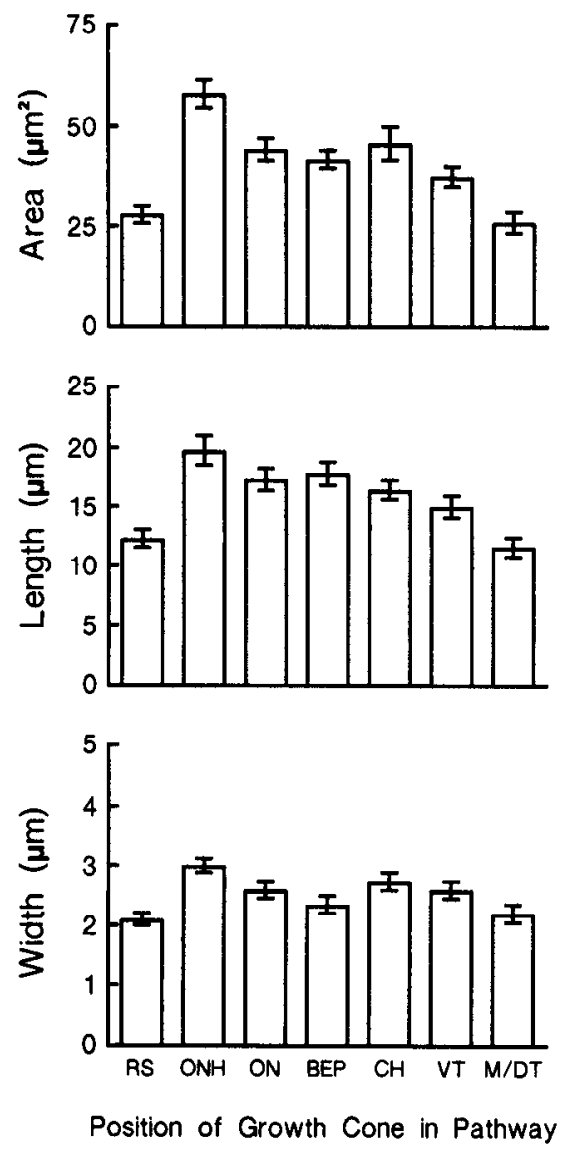

Figure 6. Growth cone size in different parts of the pathway. For abbreviations, see Figure 3. Data from the mid-and dorsal parts of the optic tract $(M / D T)$ were pooled. Error bars in this and subsequent graphs are standard errors.

times after a single injection had been made into the central retina. Examination of such preparations typically showed a heavily labeled centrally located cell body with its axon projecting ventrally into the optic nerve head with a lightly labeled axon projecting peripherally (usually dorsally) to a lightly labeled cell body (a total of 17 cases was seen). Often the growth cone of the lightly labeled cell could be seen close to the injected cell body. To check whether this was indeed coupling or an artifact due to the electrode penetrating the peripheral cell's growth cone on the way into the cell body, 3 types of control experiments were run. First, intracellular dye fills were done on retinae previously fixed for varying lengths of time in $4 \%$ paraformaldehyde. Light fixation is thought to block gap junctional communication (Spray et al., 1982). One case out of 17 was found to show "peripheral coupling" under these conditions. Howcver, during the course of these experiments it was also observed that dye coupling between cells in the skin epithelium continued to occur even after fixation times of $90 \mathrm{~min}$ so junctional coupling could not be completely ruled out. Second, in-

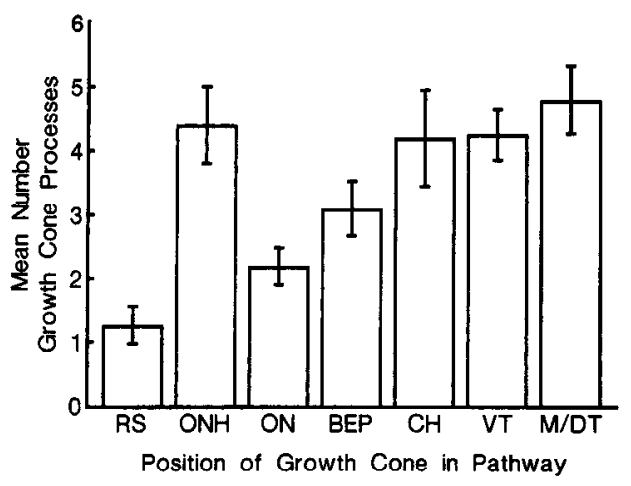

Figure 7. Growth cone complexity in different regions of the pathway. For abbreviations, see Figure 3. A growth cone process is defined as either a filopodium $>2 \mu \mathrm{m}$ in length or a lamellopodium.

tracellular injections of HRP, which is too large a molecule to pass through gap junctions, were made $(n=42)$. One clear case of "peripheral coupling" was found which was interpreted to show that this was not, in fact, coupling but resulted from inadvertent injection of HRP into the growth cone of a pheripherally located retinal ganglion cell as the electrode tip was driven into an underlying cell body. Third, support for this interpretation was borne out by the finding that no clear cases of reciprocal coupling were seen, that is, of centrally labeled retinal ganglion cells after peripheral cells were injected.

\section{Dye transfer between cells within the retina}

In addition to observing dye coupling between the cell bodies of adjacent neuroepithelial cells, it was also found that retinal ganglion cell bodies were sometimes coupled after axon initiation. In some cases, 2 retinal ganglion cells could be seen to be joined together by a cytoplasmic bridge (see Fig. 9). This suggests that sister retinal ganglion cells sometimes remain in cytoplasmic contact through at least the early stages of their differentiation. The significance of this finding is not clear, but such a phenomenon has previously been described in the early mammalian retina (Hinds and Hinds, 1974). It is possible that the dye coupling seen between all of the retinal ganglion cells with axons was mediated by a cytoplasmic connection rather than via gap junctions.

In some instances it was found that, following a single injection, a Müller cell was labeled adjacent to a retinal ganglion cell (see Fig. 10). This occurred following injections of HRP as well as LY indicating that these 2 cells are not coupled via gap junctions. The Müller cell may have become labeled by dye passing from the electrode as it passed through the Müller cell's endfoot on the vitreal surface on its way into the retinal ganglion cell body. However, the existence of cytoplasmic bridges of the sort sometimes seen between retinal ganglion cclls cannot be ruled out. [Cell-lineage analysis has revealed that these 2 cell types could be sister cells (Holt et al., 1988).] The incidence of simultaneously labeling these 2 cell types was highest around 

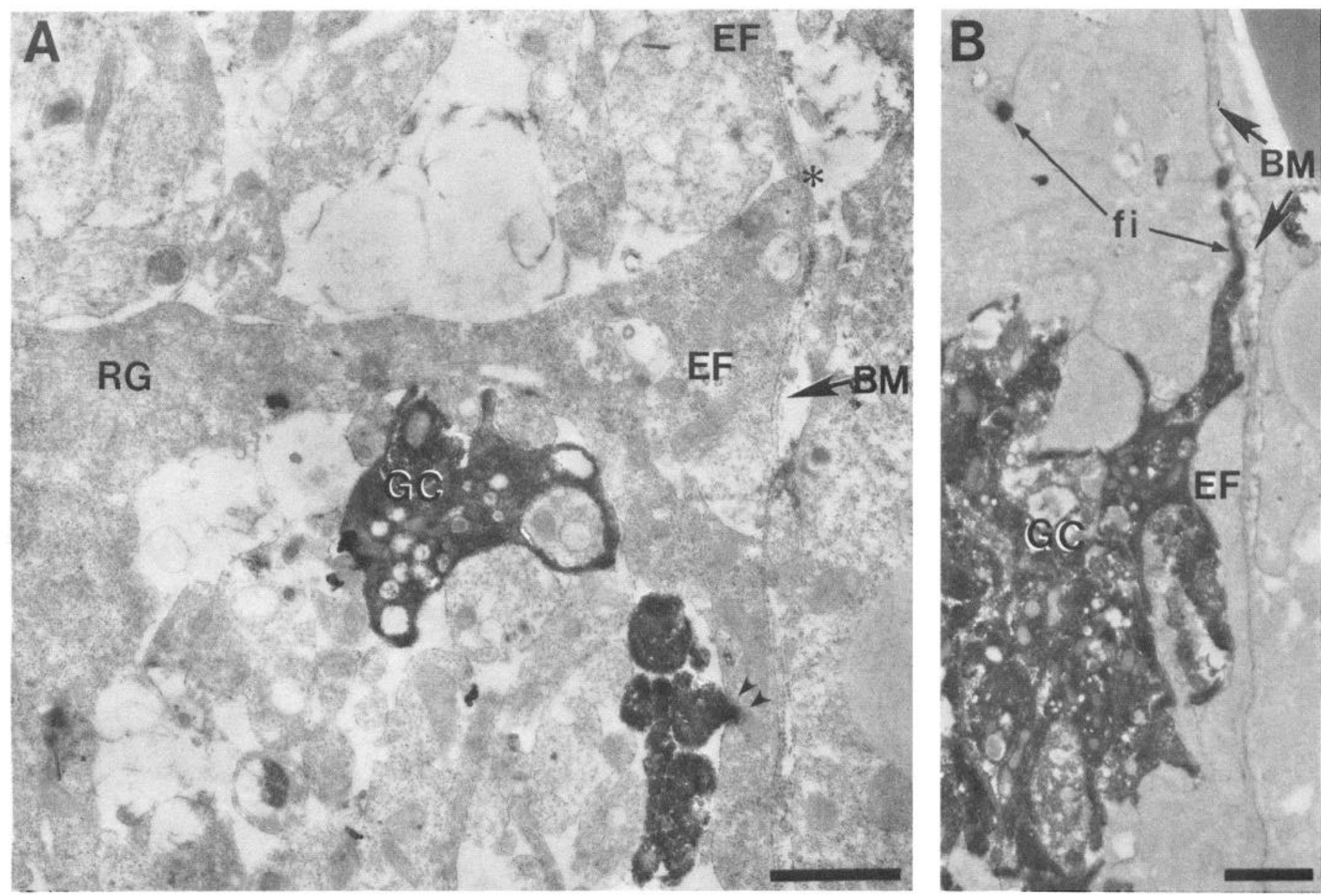

Figure 8. Electron micrographs of parts of HRP-filled pioneer growth cones in the ventral diencephalon at stage $33 / 34(A)$ and dorsal optic tract at stage $35 / 36(B)$. A, HRP-filled growth cone $(G C)$ processes closely associated with the endfoot $(E F)$ of a radial glial cell $(R G)$. The glial endfeet make a continuous layer directly beneath the basement membrane $(B M)$. The asterisk indicates the close junction between 2 endfeet. HRP-filled processes also contact and insinuate their processes around other axon profiles (of nonretinal origin) and insert into endfeet (small arrowheads). $B$, A filopodium directly apposed to the basement membrane $(B M)$. This is a rare event and occurred only once in this serially sectioned growth cone which possessed approximately 8 filopodia. The other filopodia were $0.5-10 \mu \mathrm{m}$ away from the BM. Scale bar, $1 \mu \mathrm{m}$.

stages 33/34-37/38 and declined thereafter such that it was not observed by stage 40 .

\section{Soma changes and axon development \\ Neuroepithelial cells}

Before axons are initiated (<stage 28 ) presumptive retinal ganglion cells cannot be distinguished from other potential cell types in the young retina. Injections into single cells on the vitreal layer of the central retina at stage 28 and younger or into the peripheral margin at later stages reveal elongated neuroepithelial cells which often span the whole width of the retina from the vitreal to the ventricular surface (Fig. $11 \mathrm{~A}$ ). These cells typically have expanded apical and basal ends that attach to the vitreal and ventricular surfaces, respectively. Injections of LY into these cells shows that they are often dye coupled to other (2-3) neighboring cells. Gap junctions between these cells are commonly located at the ventricular surface (Hayes, 1976).

\section{Axon emergence}

Axon initiation was seen as a polarized thickening usually at or close to the vitreal surface of the cell. This was frequently accompanied by the appearance of dark-staining knobs on the vitreal surface. These could be "test sites" of axon initiation where the cell might interact with several different areas of microterrain before deciding which position and direction to extend an axon or they could mark the beginning of dendrite formation. Axons sometimes emerged from other parts of the cell (Fig. 11, D, G) and sometimes from a primary dendrite shaft (Fig. 2). Newly initiated axons were usually wider (width $\sim 5$ $\mu \mathrm{m}$ ) than more established longer axons (width $\sim 2 \mu \mathrm{m}$ ).

In cells situated dorsal to the ventral fissure, axons usually turned ventrally on reaching the vitreal surface and headed directly towards the optic nerve head (Fig. 11). Some exceptions to this were found, however. For example, in one case, the axon of a centrally located cell headed temporally for about $15 \mu \mathrm{m}$ before correcting its course by making an abrupt turn ventrally. In rare cases, axons were seen heading dorsally. Cells situated in nasal, temporal, and ventral retina also sent their axons directly towards the ventral fissure in the majority of cases. Axons from retinal ganglion cells located at or very close to the optic nerve head showed a "looped" trajectory in that initially they grew towards the vitreal surface and then looped back on themselves to enter the optic nerve head (Fig. 14). These axons could have joined the optic nerve head directly from their point of 


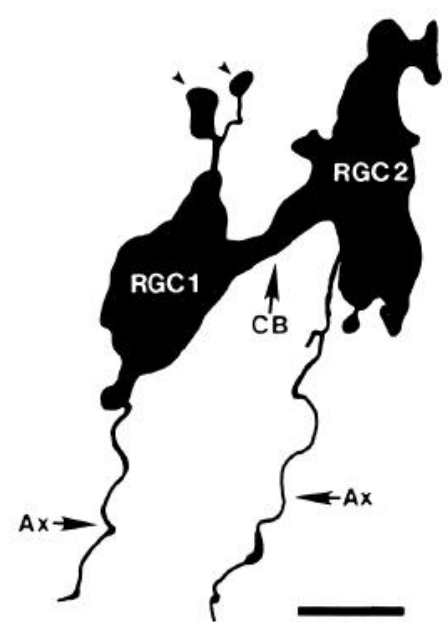

Figure 9. Whole-mount view of 2 retinal ganglion cells joined together by a cytoplasmic bridge $(C B)$. One cell body was impaled with a microelectrode in a stage $35 / 36$ retina and injected with HRP. Each retinal ganglion cell has an axon $(A x)$ that leaves the eye. Retinal ganglion cell 1 can be seen beginning to elaborate dendrites (arrowheads). The cytoplasmic bridge lay in a deep plane of focus and thus emerged from each cell at a point distant from the vitreal surface. Scale bar, $10 \mu \mathrm{m}$. emergence from the cell. Instead, they reached the vitreal surface before turning, suggesting that some guidance cues might be located there.

The morphology of retinal ganglion cell bodies that had just initiated an axon was quite variable. Some were smooth and round, some were elongated, and others had very irregular profiles. Ganglion cell size was variable ranging from 8 to $15 \mu \mathrm{m}$ in the dimensions parallel to the vitreal surface (dorsoventral and nasotemporal). Cell somas were commonly elongated in the apicobasal dimension ranging from 13 to $22 \mu \mathrm{m}$. No obvious preponderance of large-sized cells was noted, indicating that small and large classes of cells were sampled similarly. The majority of retinal ganglion cell bodies initiating axons were close to the vitreal surface. This contrasts with the cat retina, in which newly differentiating retinal ganglion cells initiate axons when their perikarya are deep to the vitreal surface outside the retinal ganglion cell layer (Maslim et al., 1986). Of course, the method of injection used here selects for cells located close to the vitreal surface so that deep-lying cells would not usually be seen. In several cases, the cell bodies were positioned deeper in the retina, midway between the 2 surfaces. These cells usually had their growth cones lying on the retinal surface and probably became labeled through injecting their growth cone. In some cases, basal processes were observed extending towards the ven-
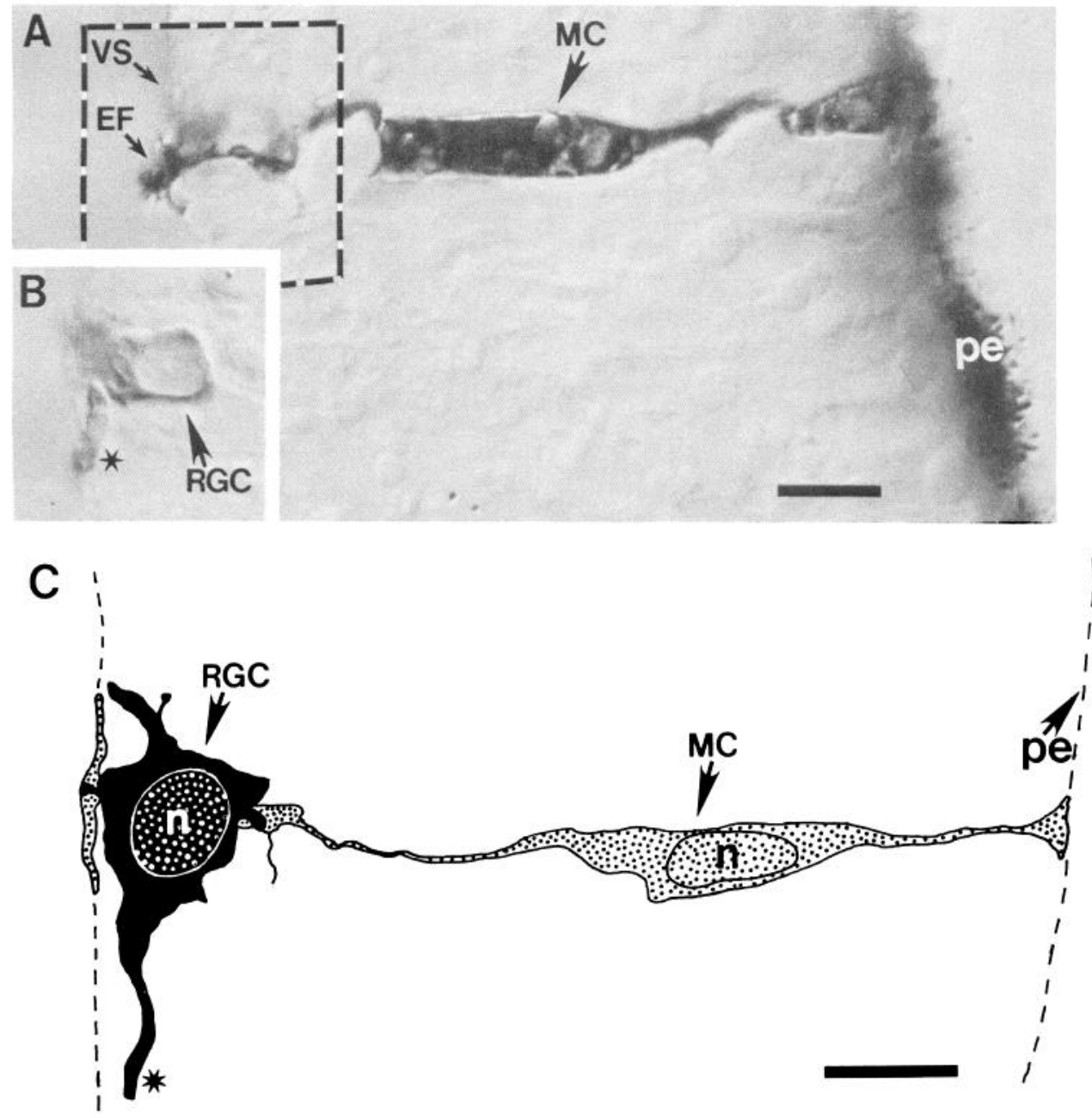

Figure 10. Two cells labeled following a single impalement. The photomicrographs in $A$ and $B$ show a labeled Müller cell $(M C ; A)$ and retinal ganglion cell $(B)$. The retinal ganglion cell, which is out of focus in $A$, is shown in $B$. It has just initiated an axon (asterisk) on the vitreal surface $(V S)$. Note that the nucleus is clearly visible. The Müller cell has endfeet expansions $(E F)$ at the vitreal surface and at the outer limiting membrane bounding the pigment epithelium (pe). From the drawing in $C$, it can be seen that the Müller cell endfoot at the vitreal surface is sinuous and expanded and lies vitread to the retinal ganglion cell perikaryon. Thus, it can be envisaged how a microelectrode might penetrate the MC endfoot on its way into the underlying retinal ganglion cell. The asterisk in $C$ marks the retinal ganglion cell axon. $n$, nucleus; $p e$, pigment epithelium. Scale bars, $10 \mu \mathrm{m}$. 

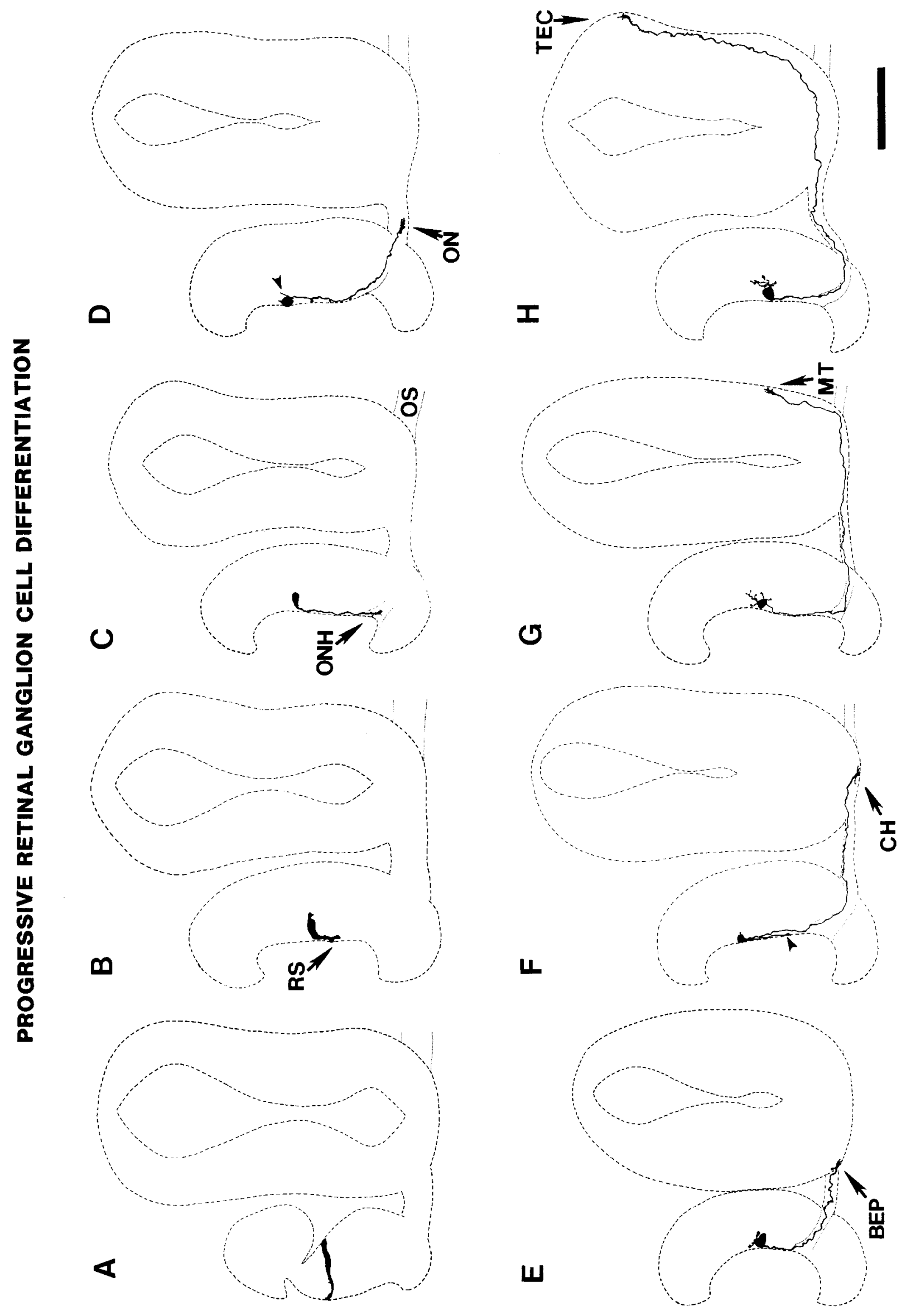

Ш

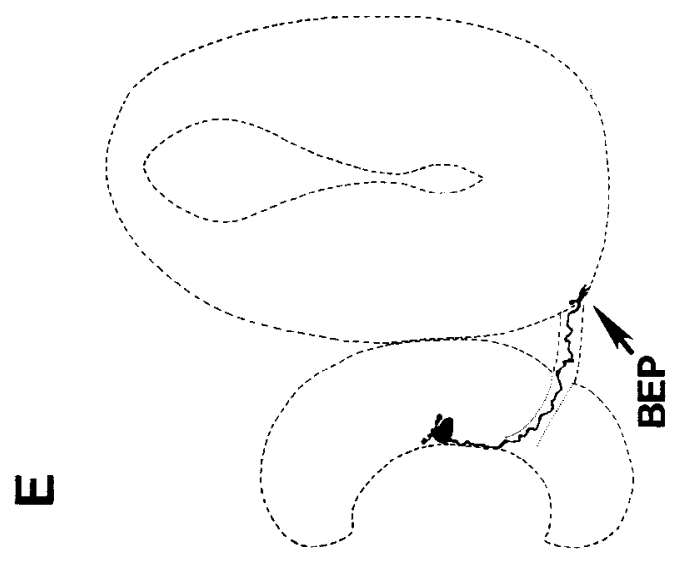


tricular surface from newly differentiating retinal ganglion cells, but these were not common and did not extend to the outer limiting membrane. This observation again contrasts with the cat retina, in which the basal processes of retinal ganglion cells remain attached until well after axon initiation (Maslim et al., 1986). In the rat, as here, basal processes are only sometimes present and these never extend to the outer limiting membrane (Maslim et al., 1986).

\section{Axon profiles and trajectories}

In general, single axons were seen to follow a direct course through the optic pathway to the tectum (see Figs. 2 and 11). Sometimes, however, sharp bends occurred in an axon's profile, indicating that the growth cone had probably made an abrupt turn at this point. Such sharp-angled bends tended to occur in certain places in the pathway. These included the entry points to the optic nerve head and to the brain, the chiasm region and, in one case, at the point in the ventral diencephalon where the contralateral optic nerve enters. In the retina, also, axons were occasionally seen to make sharp turns which usually served to reorient them back on course for the ventral fissure.

Axon profiles were smooth in some cases and beaded in others. Small side branches (2-8 $\mu \mathrm{m}$ long) were occasionally seen coming off the main axon. These side branches tended to occur in the same places in the pathway as the sharp bends, i.e., at the optic nerve head and brain entry points and the chiasm. As axons neared the target and invaded it, small side branches often appeared in the dorsal optic tract (see next section). Axons were not observed to send off long secondary branches at any point in the pathway.

\section{Axon terminals}

When an axon tip enters the optic tectum, it tends to lose its characteristic growth cone morphology and to become "hairy" sending out small side branches along its shaft (Fig. 12). The terminal portion of the axon tends to be thicker than in the pathway and has swellings, varicosities, and spikes. Newly arrived terminals showing this type of morphology are often unbranched and lie close to the pial surface (Figs. 12, $A, B$ ). More mature terminals are usually located deeper in the neuropil, although a part of them often remains close to the surface, and have complex branching patterns extending over some distance rostrocaudally (Fig. 12C).

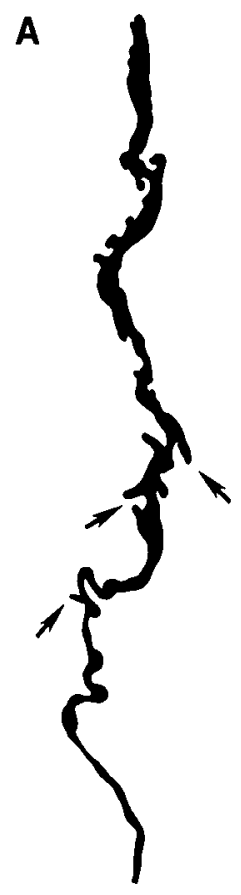

B

C

Figure 12. Newly arrived axon terminals in the tectum. Camera lucida drawings of axon tips from a whole-mount preparation $(B)$ and reconstructed from transverse sections $(A, C)$ in 3 different stage 39 animals. The terminals are typically thickened and possess numerous small sidc branches (see $B$ and arrows in $A$ ) along much of their length. Growth cones which characteristically tip axons throughout the pathway (see Figs. 4,5 ) are usually absent in the tectum (except see Fig. 4I). All 3 terminals lie close to the pial surface (within $\sim 5 \mu \mathrm{m}$ ). The terminal in $C$ travels approximately $30 \mu \mathrm{m}$ caudally from its point of entry into the tectum and has begun to arborize as indicated by the 4 separate branches. This terminal is probably more mature than terminals $A$ and $B$. Scale bar, $10 \mu \mathrm{m}$.

\section{Retinal ganglion cells with 2 axons}

An unusual finding was that some of the retinal ganglion cells send two axons, and occasionally three axons, into the optic pathway. Most commonly, two axons are seen emerging from different points on the cell body (Figs. 13A, 14). In somc cascs, however, a single axon can be seen to bifurcate within the retina

Figure 11. Steps in the early differentiation of retinal ganglion cells. Dashed lines show the outlines of the midbrain and retina (each outline is a composite of 2-4 transverse sections). LY-filled immunolabeled retinal ganglion cells (solid) were drawn using a $100 \times$ objective and reconstructed from 2-6 $40 \mu \mathrm{m}$ sections. $A$, Neuroepithelial cell spans the width of the retina at stage 27 . Note the terminal expansions at the inner and outer limiting membranes. $B$, Retinal ganglion cell with a recently initiated axon lying on the retinal surface $(R S)$ at stage 28 . Note the thickness of this initiating axon (approx. $4 \mu \mathrm{m})$ compared with that of longer axons in $C-H(1-1.5 \mu \mathrm{m})$. The perikaryon is elongated and close to the vitreal surface. The small basal expansion could be a remnant of the cell's earlier attachment to the ventricular surface during its germinal phase. $C$, Retinal ganglion cell with an axon extending directly towards the optic disk; its growth cone is turning into the optic nerve head $(O N H)$ at stage $33 / 34$. Dendrites have not yet begun to form. $D$, Retinal ganglion cell with its growth cone in the optic nerve $(O N)$ at stage $29 / 30$. This particular sample was fixed for $75 \mathrm{~min}$ in paraformaldehyde before injection. A process extending from the basal part of the cell (arrowhead) and one extending dorsally are probably dendrites beginning to form. $E$, Retinal ganglion cell with its growth cone just entering the ventral diencephalon (brain entry point, $B E P$ ) at stage $33 / 34$. Two dendrites each with terminal varicosities are extending from the cell body: one towards the vitreal surface and the other towards the ventricular surface. $F$, Retinal ganglion cell with 2 axons at stage 35/36: one with its growth cone at the chiasm $(\mathrm{CH})$ and the other on the retinal surface (arrowhead). $G$, Retinal ganglion cell with 4 dendrites, one of which has 2 branches, and its growth cone in the mid-optic tract $(M T)$ at stage 33/34. Note that the axon makes $290^{\circ}$ turns: one at the $\mathrm{ONH}$, another close to the contralateral optic nerve entry point. $H$, Retinal ganglion cell with 5 dendrites emerging from a single shaft and its growth cone in the optic tectum (TEC) at stage $35 / 36$. Note the small side branches emitting from the axon in the tectum/dorsal optic tract and one opposite the contralateral optic nerve entry point. Also note the abrupt L-bend in the axon at the point of entry into the brain. $O S$, optic stalk. Scale bar, $100 \mu \mathrm{m}$. 


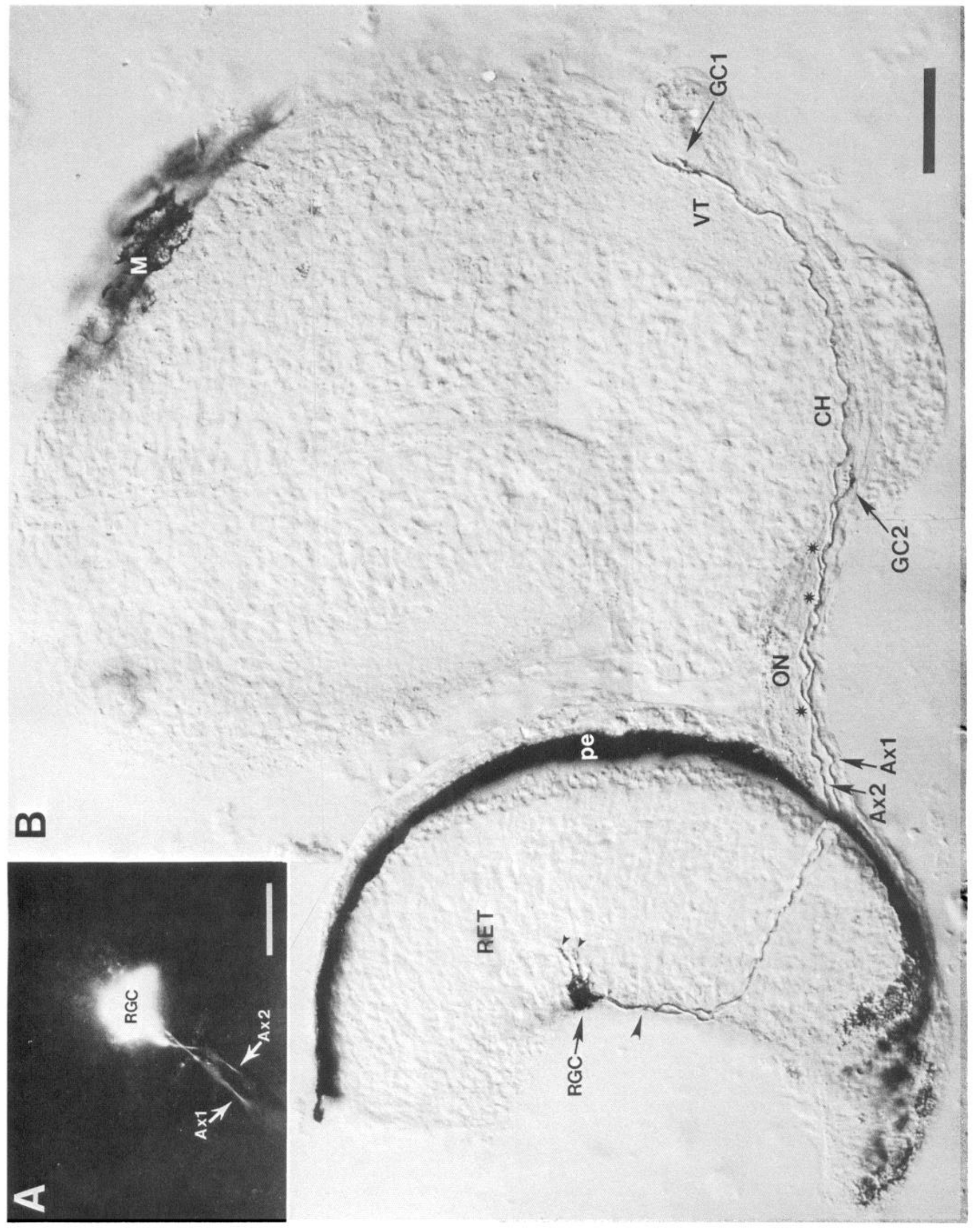




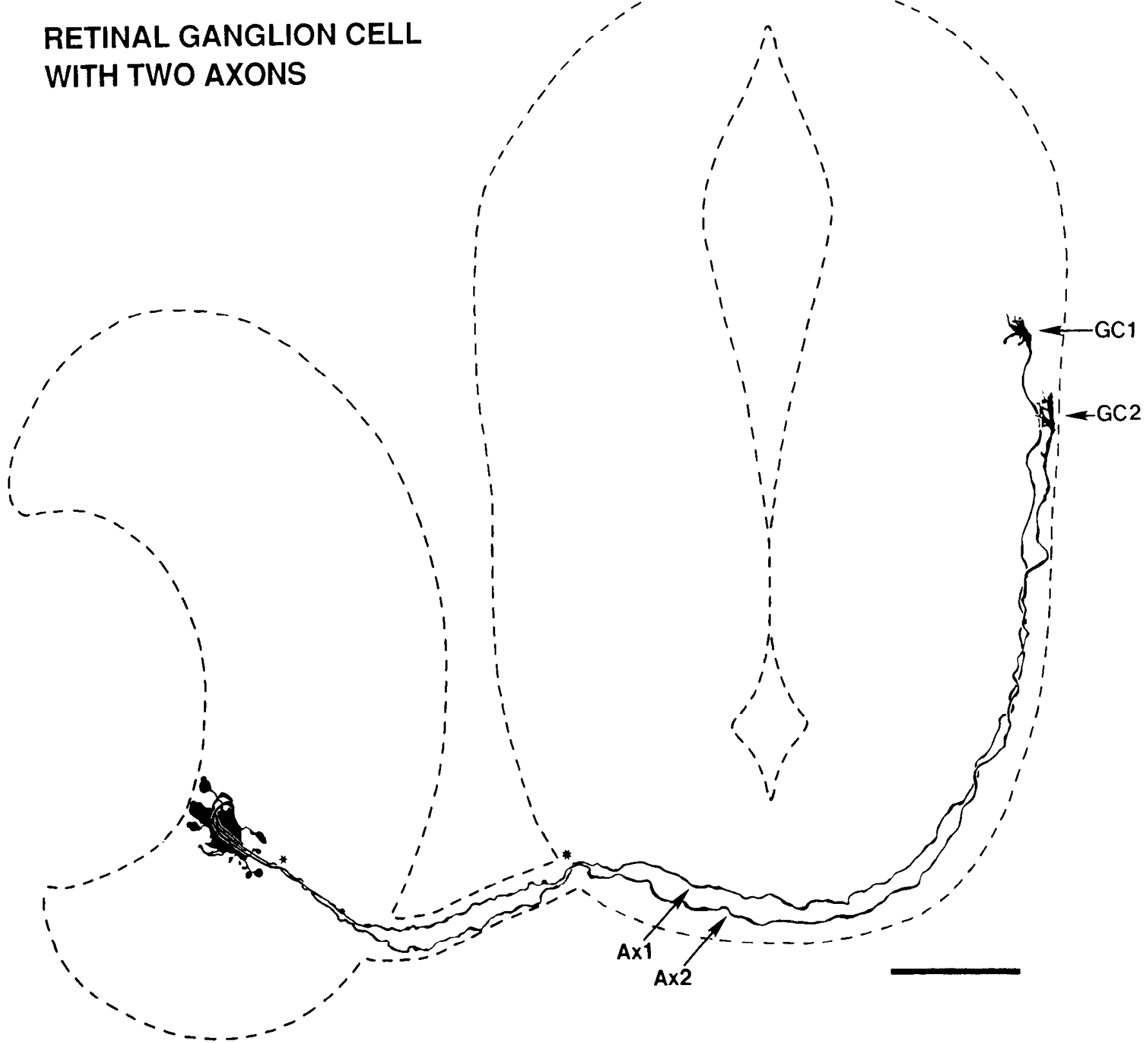

Figure 14. Camera lucida drawing of a retinal ganglion cell with 2 axons in the pathway at stage 37/38. Each axon emerges separately from the cell body and has a characteristic looped trajectory in which it extends initially towards the vitreal surface before turning back on itself to join the optic nerve head. In the looped part of their trajectory, each axon comes into close contact with the vitreal surface, as do the apical dendrites. This is not apparent in this compressed representation of a $40 \mu \mathrm{m}$ section, where the dashed line indicating the position of the vitreal surface was drawn in the focal plane of the dendrites, some $15 \mu \mathrm{m}$ deep to the axons. The 2 axons run close to each other within the optic nerve head in the retina but travel separately and distant from each other in the optic nerve and pathway. In the optic tract, Ax 1 travels $10-20 \mu \mathrm{m}$ rostral to Ax 2 . The axons cross over in the optic nerve head and again when they enter the ventral diencephalon (asterisks). The 2 growth cones are located in the mid-to-dorsal optic tract and both possess numerous filopodia. The cell body has begun to elaborate several dendrites tipped with large varicosities, possibly dendritic growth cones. Scale bar, $50 \mu \mathrm{m}$.

Figure 13. Retinal ganglion cells with 2 axons. A, Fluorescence micrograph of a retinal ganglion cell in a whole-mount preparation soon after intracellular LY injection. Two axons $(A x 1, A x 2)$ emerge from 2 different points on the cell body and cross over approximately $10 \mu \mathrm{m}$ from the cell body. $B$, Composite photomicrograph of a cell with 2 axons (6 sections, 12 different focal planes of a stage $37 / 38$ embryo). The preparation was immunolabeled with HRP following LY injection. A single axon bifurcates (large arrowhead) some $20 \mu \mathrm{m}$ from the cell body. The 2 axons $(A x 1, A x 2)$ cross over one another 3 times (asterisks) into the optic nerve $(O N)$ and are of different lengths with one ending in a growth cone ( $G C^{\prime}$ 2) soon after entering the ventral diencephalon and the other $(G C 1)$ in the contralateral ventral optic tract (VT). Both growth cones are fairly complex having several filopodia. Two dendrites (small arrowheads) emerge from the cell body. The pigment on the upper-right surface of the brain is from melanocytes $(M)$ inadvertently left in place through the dissection. $R E T$, retina; pe, pigment epithelium; $C H$, chiasm. Scale bars: $A$, $20 \mu \mathrm{m} ; B, 50 \mu \mathrm{m}$. 


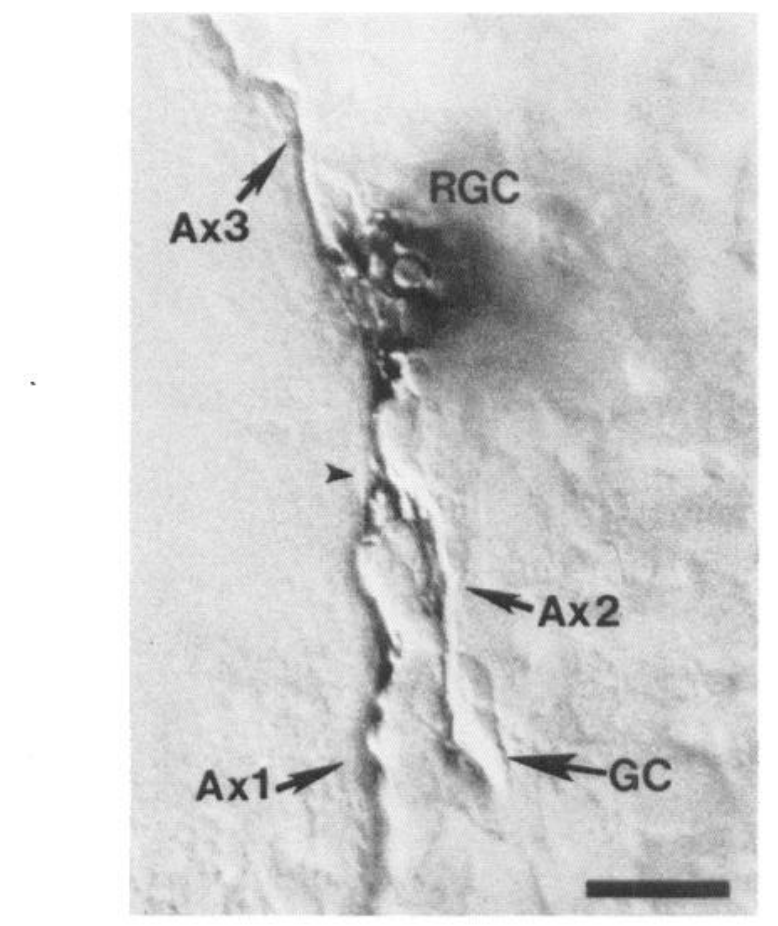

Figure 15. Retinal ganglion cell with 3 axons. This retinal ganglion cell was situated in the dorsal part of the central retina at stage $35 / 36$. A single axon emerges ventrally from the cell body and splits in 2 (small arrowhead) approximately $10 \mu \mathrm{m}$ away. One axon $(A x 1)$ exits the retina and terminates in a complex growth cone in the ventral optic tract. Ax 2 ends in a simple type of growth cone ( $G C$; with no filopodia) some $30 \mu \mathrm{m}$ from the cell body and $10 \mu \mathrm{m}$ from the vitreal surface. Ax 3 emerges dorsally from the cell body close to the vitreal surface and extends approximately $45 \mu \mathrm{m}$ dorsally, where it terminates in a small, round swelling some $10 \mu \mathrm{m}$ basal to the vitread. Scale bar, $10 \mu \mathrm{m}$.

some $10 \mu \mathrm{m}$ away from the cell body (Fig. 13B). Bifurcations of this sort were not seen outside the retina.

The possibility that these double-axon cases resulted from 2 cells whose separate identities were not distinguishable in the sectioned material was tested in 2 ways: (1) by making intracellular injections of cells with HRP, which is too large a molecule to pass through gap junctions, and (2) by resectioning 40 $\mu \mathrm{m}$ sections at $5 \mu \mathrm{m}$ in plastic and using a nuclear counterstain (fuchsin or hematoxylin) to identify the number of nuclei per HRP- or LY-filled cell. Retinal ganglion cells with 2 axons were found following HRP injections showing that the LY-filled retinal ganglion cells with more than one axon are probably not coupling artifacts. However, coupling of 2 cells via a cytoplasmic bridge could not be completely ruled out. Of 26 cases classified as having multiple axons, 7 were resectioned at $5 \mu \mathrm{m}$. Four of these were seen to possess just 1 nucleus, 2 others could not be classified (the boundaries of the nuclei were unclear) and one, a 4-axon case, contained 3 nuclei. The nuclei of HRP- and LYfilled cells were often less densely labeled than the cytoplasm and so could be distinguished in the $40 \mu \mathrm{m}$ sectioned material (see the nucleus in the retinal ganglion cell in Fig. 10A, for example). Seven further cases could be classified in this way as containing one nucleus while possessing 2 axons. Thus, of 190 cases in which retinal ganglion cells had extended an axon at least $15 \mu \mathrm{m}$ from their soma, the frequency of occurrence of retinal ganglion cells with more than one axon was estimated at approximately $5 \%$ (11 definite multiple axon cases out of
190). This figure is probably an underestimate since it does not include the cases in which it was not possible to see the nucleus clearly and may be closer to $10 \%$. In most of the double-axon cases, both axons headed directly to the optic nerve head and left the eye. In 4 cases, however, one of the axons was seen to travel dorsalward in the opposite direction from the other one (see Fig. 15). These axons were short (15-20 $\mu \mathrm{m}$ ), and their tips remained close to the vitreal surface and showed typical retina growth cones.

\section{Trajectories of 2 axons from same retinal ganglion cell}

Two axons from the same parent cell travel completely independently in the pathway. They do not fasciculate with one another or even follow each other closely in the pathway. Indeed, in Figure 14, which shows 2 axons emerging from a cell close to the optic nerve head, the 2 axons are widely separated in the optic nerve, come together for a short distance at the point of brain entry, then follow disparate trajectories throughout the ventral diencephalon and optic tract. Their growth cones are positioned in the dorsal optic tract. In the optic nerve head, they do travel close to one another, but this is not always the case. Two axons are frequently seen to cross over one another, sometimes 3 or 4 times, particularly in the optic nerve and in the ventral diencephalon close to the point of optic nerve entry (Figs. 13,14). The 2 axons can be of similar length as shown in Figure 14, or quite different lengths as in Figures $11 \mathrm{~F}$ and 13 , indicating that the 2 axons are probably initiated at different times. The growth cones at the tip of axons sharing a common parent cell have different morphologies, suggesting that growth cone morphology is not controlled by intrinsic cell-type specific factors.

None of the double-axon cases observed in this study had reached the tectum. This probably reflects the fact that fewer injections were made at the later stages (39-41). It would be interesting, however, to find out where the 2 axons terminate. For example, one of the axons might be sent to the thalamus and the other to the tectum. Also, one would like to know whether these second axons survive into later stages of development.

\section{Dendrite development}

\section{Dendrite emergence: appearance and position}

Newly initiated dendrites are characteristically tipped with small rounded knobs or varicosities ranging from 1 to $5 \mu \mathrm{m}$ in diameter (Figs. 16, 17). These knobs might be dendritic growth cones; however, they lack filopodial or lamellopodial extensions characteristic of axonal growth cones and of dendritic growth cones in other systems (Maslim et al., 1986). They are also much smaller than axonal growth cones (3-6 $\mu \mathrm{m}$ long compared with $12-20 \mu \mathrm{m})$. The dendrite shafts are much thinner than a newly extended axon shaft (compare dendrite shafts in Figure $17 C$, approximately $0.2 \mu \mathrm{m}$ across, with the newly initiated axon in Fig. $11 B$, approximately $5 \mu \mathrm{m}$ across).

Dendritic knobs first emerge from the basal and sometimes from the apical regions of the cell body (Figs. 16, 17). Apical dendrites tended to reach their varicose tips to contact the vitreal surface. Their occurrence became less common after the axon had reached the optic tract, and they were not observed in cells whose axons had invaded the target suggesting that they are a transient developmental phenomenon. This is consistent with similar observations made in the young mammalian retina (Ramón y Cajal, 1972; Hinds and Hinds, 1974). Sometimes retinal 

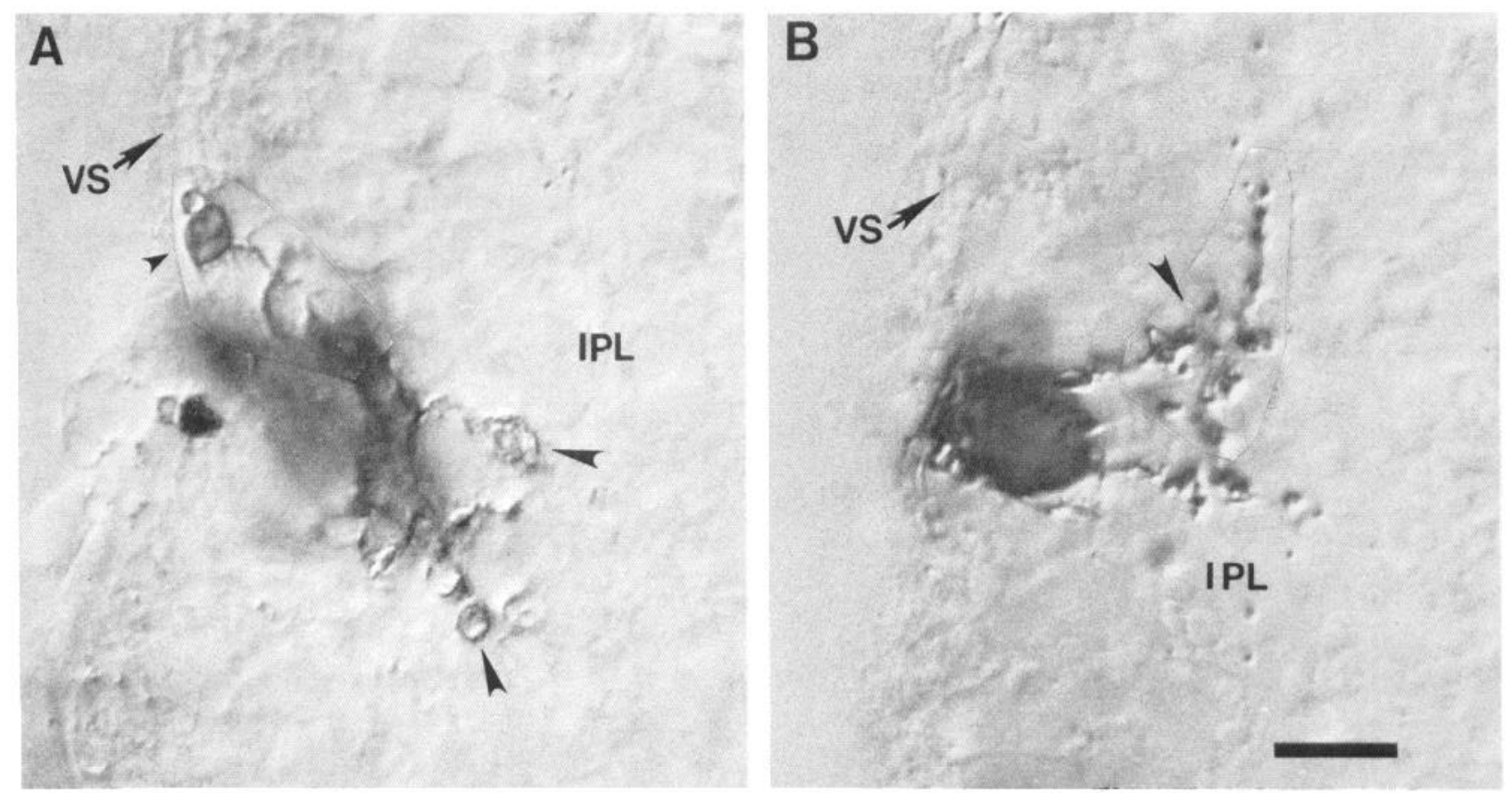

Figure 16. Early dendrite genesis. A, Photomicrograph of the retinal ganglion cell body shown in Figure 14. Large varicosities, possibly growth cones, are present at the tips of these nascent dendrites (arrowheads). Some extend towards the inner plexiform layer (IPL; large arrowheads), whereas others extend vitreally (small arrowhead). Note the small diameter of the dendrite shafts. The axons (this is a 2-axon cell, see Fig. 14) of this cell terminate in the mid-dorsal optic tract. $B$, Photomicrograph showing dendrites beginning to branch (large arrowhead indicates branch point) in the IPL. At this slightly later stage of dendrite development, dendrite shafts are thicker than initially, possess blobs, and varicosities along their lengths and not specifically at their terminals. This cell lies in the central part of a stage $35 / 36$ retina and its axon had just arrived in the optic tectum. $V S$, vitreal surface. Scale bar, $10 \mu \mathrm{m}$.

ganglion cells had a trailing basal process (probably a remnant of the neuroepithelial endfoot), and it appeared as if this process itself might shorten and mature into a dendrite.

\section{Time of dendrite emergence with respect to axon position}

Dendrites began to develop before the cell's axon had reached the tectum, although the number of dendrites and their complexity was often variable. Usually, the axon emerged from the cell body well before dendrites appeared, but this was not always the case. Sometimes 1 or 2 dendritic knobs could be seen extending from the cell body when the axon tip had only extended about $10 \mu \mathrm{m}$. The majority of cells whose axons had reached the tectum possessed an extensive dendritic arbor. An analysis of dendrite formation was performed on 188 retinal ganglion cells. The axons of each of these cells could be traced into the pathway so that the pattern of dendrite elaboration could be related to the position of the growth cone and thus to axon length. The percentage of retinal ganglion cells that possessed dendrites and the mean number of dendrites per cell were found to increase progressively with increasing axon length (Fig. 18), so that the closer the growth cone was to the tectum the more likely the cell soma was to possess dendrites. For example, only $20 \%$ of retinal ganglion cells have dendrites when their growth cones are within the retina. This figure rises to 90 and $100 \%$ when the growth cone reaches the mid-to-dorsal optic tract and the optic tectum, respectively. There is considerable variability as can be seen in Figure 11 in the stage of dendrite development and the position of the axon tip in the pathway. For example, the cell in Figure $11 E$ whose axon tip has not extended as far as the cell in Figure $11 \mathrm{~F}$ has elaborated more dendrites. The retinal ganglion cells examined in the present study were among the earliest population of cells to send optic fibers into the tract; therefore, axon distance along the pathway correlates with the age of the animal. To determine whether dendrite emergence is related more to individual retinal ganglion cell maturity or to the age of the embryo, and thus the surrounding microenvironment of the retinal ganglion cell, several statistical analyses were run. The number of dendrites per cell correlated both with age and axon length, however, the correlations with axon length were clearly higher (see Table 2). To separate the effects of age versus axon length, a multiple-regression analysis was run. It showed that axon length but not stage was a significant indicator of dendrite number (see Table 2). Therefore, retinal ganglion cells with longer axons tend to have more dendrites.

\section{Dendrite branching}

Dendrite branching (see Fig. 17) begins after 3 or more primary dendrites have been extended and after the retinal ganglion cell axon has entered the pathway. The possibility that target contact is necessary for initiating branching was investigated by examining the temporal relationship of branching and target arrival (Fig. 18). It was found that branching begins in $\sim 40 \%$ of the cases with dendrites before the axon tip reaches the target. The incidence of branching in cells with short axons was low ( 1 out of 12 cases with growth cones in the retina) and rose progressively as the axon extended further along the pathway (4 out of 9 cases in the mid-to-dorsal optic tract).

In summary, at early stages of axon extension when the growth cone is located in the ipsilateral stretch of the pathway, dendrites are short, few in number (1-3), tend to end in knobs, and are unbranched (Fig. 18). As development proceeds and the axon reaches the contralateral stretch of the pathway, dendrites be- 


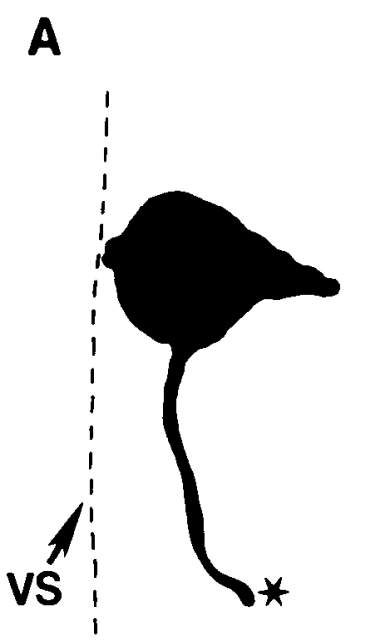

D

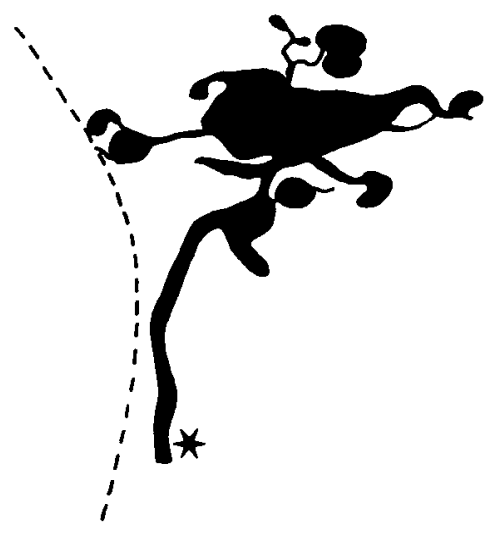

B

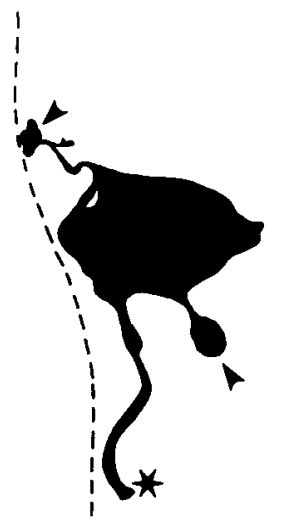

$\mathbf{E}$

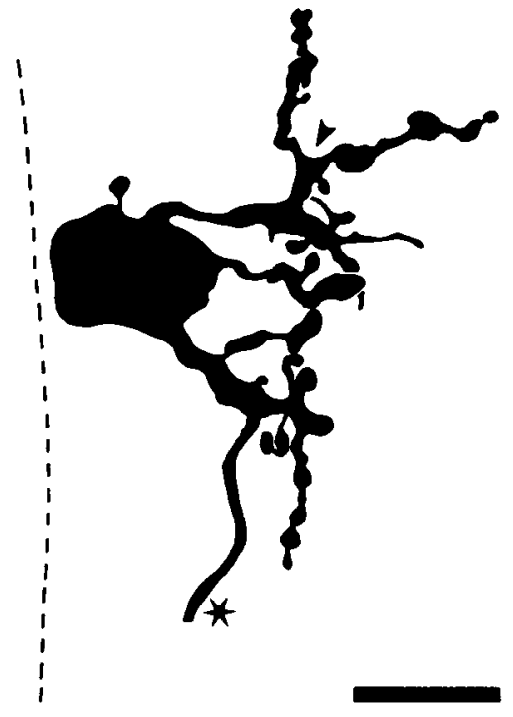

C

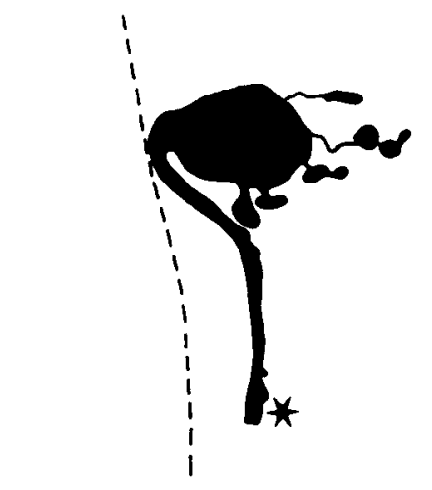

\section{C}

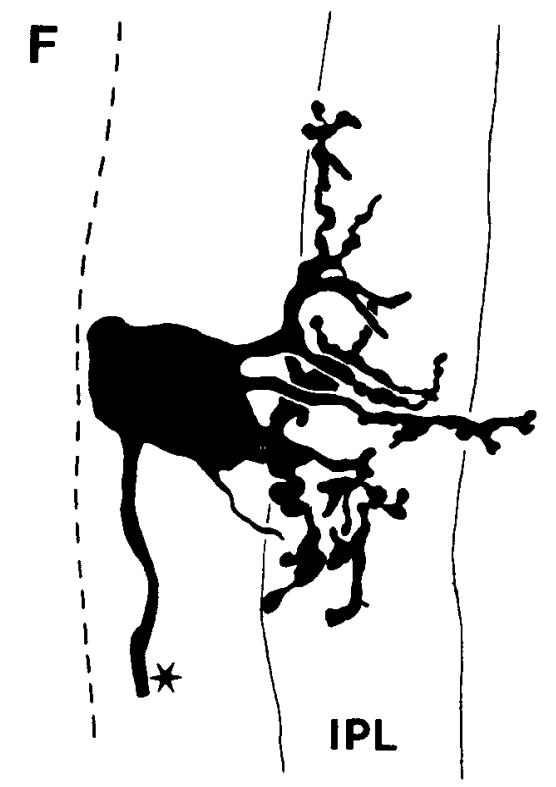

Figure 17. Progressive dendrite formation. Camera lucida drawings of the cell bodies of retinal ganglion cells all of which have axons (asterisks) that leave the retina and enter the optic pathway. The growth cones are located at the brain entry point $(B)$, the ventral optic tract $(A, C, D)$, the mid-optic tract $(E)$, and the optic tectum $(F)$. A, A retinal ganglion cell body with an axon and possibly the remnant of its basal endfoot; dendrites have not begun to form. $B$, Two dendrites have formed (arrowheads) each with large terminal varicosities; one is closely apposed to the vitreal surface. $C$, Five separate dendrites project from the cell body. Each is tipped with a characteristic round swelling. $D$, Five main dendrite shafts have formed; 2 of these have begun to branch (see dorsal and vitreal extending dendrites). Three dendrites project from the initial axon segment. $E$, Three primary dendrites with several branch points (see arrowhead, for example) extend from this stage 35/36 retinal ganglion cell. Two dendrites run parallel to the VS in the inner plexiform layer and have a beaded appearance. The axon and the most ventral of the primary dendrites run together out of the cell body approximately $15 \mu \mathrm{m}$ before they separate. $F$, Four primary dendrites extend from this stage 40 retinal ganglion cell; 3 of these are extensively branched; the fourth is small and unbranched. The majority of dendrites ramify in the vitread portion of the IPL. Scale bar, $15 \mu \mathrm{m}$.

come more numerous and longer and begin to branch. By the time axons have reached the tectum, the majority of retinal ganglion cells have complex dendritic arbors that are multiply branched.

\section{Discussion}

This is the first study to examine the morphogenesis of retinal ganglion cells in the vertebrate CNS from soma to axon tip.
Several significant new findings have emerged. (1) Dye coupling does not appear to occur between growth cones and the cells they pass in the pathway. (2) Growth cones change their size and shape in a position-dependent way: Their increased complexity and size at the optic nerve head identifies this as a specialized region of the pathway. (3) Retinal ganglion cells sometimes send out more than one axon into the pathway. (4) Initial dendrite development does not depend on the axon contacting 
the target and correlates better with individual retinal ganglion cell age rather than with the age of the embryo. These results are discussed separately below.

\section{Growth cones and gap junctional communication}

Growth cones of retinal ganglion cells probably do not make dye-coupling junctions with cell bodies that they pass in the pathway from the retina to the tectum. This contrasts with findings in other systems where this question has been investigated, notably the grasshopper CNS (Taghert et al., 1982) and PNS (Bentley and Keshishian, 1982) and the zebrafish motoneurons (Eisen et al., 1989), where growth cones are commonly seen to pass LY dye to particular cells in their immediate vicinity. Dye transfer between coupled epithelial cells in the retina and in the skin was fairly rapid (within 2 min), was easily detectable, and was reproducible under the different experimental conditions used (e.g., with or without anesthetic), indicating that gap junctional communication, at least in these cells, was functional and robust. The level of LY staining in individual growth cones was usually intense; in fact, the growth cone was often more densely labeled than the cell body, which argues against the possibility that the levels of dye were too dilute in the growth cone to detect its transfer to neighboring cells. Short postinjection survival times $(2-5 \mathrm{~min}$ ) were the norm throughout the study; however, several longer postinjection survival times (up to $90 \mathrm{~min}$ ) indicated that the absence of coupling was probably not due to there being insufficient time for the dye to transfer from the tip. Moreover, the dye filled the axon tip even when it had reached the tectum (a distance of $\sim 800 \mu \mathrm{m}$ ) after short ( $2 \mathrm{~min}$ ) postinjection survival times.

Direct communication between the interiors of adjacent cells mediated via gap junctions is widespread in the early embryonic development of many multicellular organisms (Furshpan and Potter, 1968; Blackshaw and Warner, 1976; Goodman and Spitzer, 1979; Guthrie, 1984). Their abundance at times when determinative events are occurring in embryogenesis has led to the suggestion that gap junctions may play a major role in the
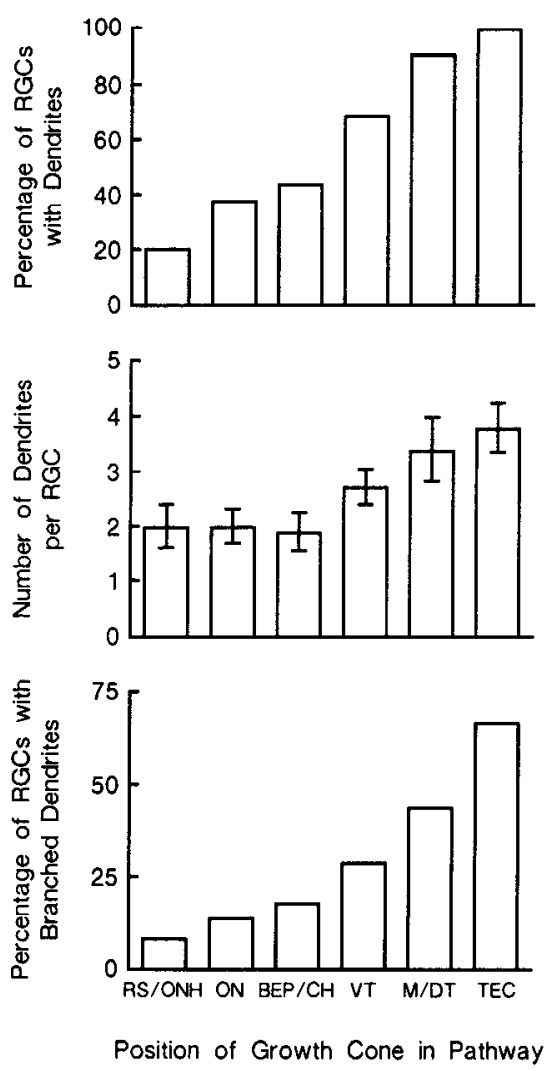

Figure 18. Dendrite development (number and branching) plotted against the position of the retinal ganglion cell's growth cone in the pathway.

transmission of as yet unidentified regulatory signals important for growth control, pattern formation, and differentiation (Furshpan and Potter, 1968; Lo, 1980; Caveney, 1985). Indeed, blockage of gap junctions by injection of anti-gap junction antibodies into CNS-fated blastomeres of early Xenopus embryos

Table 2. Number of dendrites versus stage and position of growth cone in the pathway

I. Multiple-regression analysis

\begin{tabular}{llll} 
Parameter & $F$ value & $\begin{array}{l}\text { Residual } \\
\text { mean square }\end{array}$ & $\begin{array}{l}\text { Significance } \\
\text { level }\end{array}$ \\
\hline $\begin{array}{l}\text { Dendrites correlated with position and stage }(n) \\
\text { Dendrites correlated with position only }(n)\end{array}$ & 22.7 & 308.3 & 0.001 \\
II. Correlation coefficients & 41.1 & 314.5 & 0.001 \\
& & $r$ & $\rho$ \\
\hline Dendrites correlated with position $(n)$ & & 0.425 & 0.419 \\
Dendrites correlated with stage $(n)$ & 0.334 & 0.390 \\
Position correlated with stage & & 0.531 & 0.507
\end{tabular}

Part I shows some results from a multiple-regression analysis on 188 retinal ganglion cells, where the number of dendrites was regressed against stage of the animal containing the analyzed ganglion cell and the distance along the pathway (position) of its growth cone. When both variables were used, the $F$ value was lower than when, in a stepwise regression, only position was used. Adding stage as a variable resulted in only a very small decrease of the residual mean squared. Furthermore, the significance value of adding the stage variable to the model based on position only was $>0.05$. All these findings indicate that the position of the growth cone is a better indicator of the number of dendrites, than is the stage of the animal.

Part II shows correlation coefficients ( $r$ ) and Spearman's rank correlation coefficients $(\rho)$ for number of dendrites, distance of growth cone along the pathway (position), and stage of the animal, based on 188 retinal ganglion cells. As can be seen from both these measures, number of dendrites correlates better with position than with stage. The correlation between number of dendrites and stage may simply be the result of the high correlation between position and stage. This is in accord with the multiple-regression data, above. 
results in severe neural deficits strongly implicating the involvement of gap junctions in early determinative events of the CNS (Warner et al., 1984). Widespread coupling has been described between the neuroepithelial cells of the retina before axonogenesis begins in the Xenopus eye primordium (Dixon and CronlyDillon, 1972; Fujisawa et al., 1976; Hayes, 1976; Sakaguchi et al., 1984), and, as the present study reveals, may even occur somctimcs whilc axons arc being extcnded. Thus, intcrcellular communication may be important in determining cell fate in the retina; however, it appears not to play a major role in axonal navigation.

\section{Growth cone morphology and the optic pathway}

The growth cones of retinal ganglion cells change their size, profiles, and degree of complexity in a characteristic way as they extend along the pathway. The most striking change is seen when growth cones leave the retinal surface to enter the optic nerve head where they become elongated, often 2-3 times the length of those on the retinal surface, and possess numerous filopodia. What regulates these changes in growth cone morphology? One possibility is changes in the local environment. Indeed, at the optic nerve head growth cones encounter a new microterrain: At this point, they leave the retinal surface where they have been growing along the endfeet of neuroepithelial cells and dive deep into the retina along the shafts of neuroepithelial cells. The change in morphology and size in this region may simply reflect the growth cone's response to an abrupt physical change in the microenvironment. Alternatively, or perhaps additionally, specific guidance cues may be located on the surfaces of cells in this region and the growth cone's change in behavior may signify an active sampling of the substrate through its increased area and filopodial contacts. It has been observed in other systems that pioneer growth cones change their form becoming more complex at decision points in the pathway (Raper et al., 1983; Tosney and Landmesser, 1985; Caudy and Bentley, 1986a, b; Bovolenta and Mason, 1987). For instance, motoneuron growth cones in the chick are larger and have more lamellopodia in the plexus region where fiber pathways diverge (Tosney and Landmesser, 1985) and similarly in the grasshopper nervous system, large and highly complex growth cone profiles occur at divergent junctions (Raper et al., 1983; Caudy and Bentley, 1986a), suggesting that molecular information available at these sites can be read and subsequently transduced into directional growth changes. The entrance to the optic nerve head does not represent a true choice point in the sense that axons do not take divergent routes at this juncture; however, axons do substantially change thcir course here making $45^{\circ}$ turns. The present results are consistent with the idea that this change in direction is a selective process in which growth cones actively choose to leave the retinal surface and enter the optic nerve head. Growth rate also can affect growth cone morphology (Argiro et al., 1984) and may be an additional influencing factor in growth cone changes along the pathway. In the optic tract, growth cones advance at a fairly constant rate $(\sim 50 \mu \mathrm{m} / \mathrm{hr}$; Harris et al., 1987) and show similar morphologies from ventral to dorsal optic tract. When they reach the tectum they slow down and lose their characteristic growth cone morphology. Growth rates outside the optic tract have not been monitored, so it is not known whether growth cones slow down, for example, at the optic nerve head.

Other special regions in the primordial visual pathway might be the brain entry point, where for the first time in their journey visual fibers encounter fibers of nonretinal origin traveling in different directions to themselves, and the chiasm, where axons meet fibers coming from the other eye. In each of these regions the growth cones were found to be complex, having 3 or more filopodia and were intermediate in length. Although they did exhibit significantly more filopodia than those in the adjacent region of the optic nerve, their size and complexity was not markedly different from those in the adjacent ventral optic tract. Thus, growth cones within the ventral diencephalon (from the brain entry point to ventral optic tract) display similar morphological characteristics. In the chiasm of mouse embryos, growth cones have been found to exhibit more complex profiles than elsewhere in the tract (Bovolenta and Mason, 1987). This finding contrasts with the present results and may reflect the fact that in the mouse a partial decussation occurs at the chiasm so that a significant fraction of early axons grow ipsilaterally to innervate the lateral geniculate nucleus. In Xenopus, an ipsilateral projection to the thalamus does not develop until late in larval life (Hoskins and Grobstein, 1985), although even at early stages a few fibers can often be seen to travel ipsilaterally (Sakaguchi and Murphey, 1985). Thus, the increased complexity in growth cone morphology seems to reflect that the chiasm of the mouse is a place where divergent pathway choices must be made. It should be noted, however, that the level of complexity of growth cones at the chiasm of the 2 species is very similar. The difference arises from the fact that the regions flanking the chiasm contain simpler profiles in the mouse but complex ones in Xenopus.

The time of outgrowth into the pathway did not seem to affect growth cone shape since the tips of pioneer and follower fibers were seen to display similar morphologies and levels of complexity. This agrees with similar observations of early and late classes of motoneuron (Tosney and Landmesser, 1985), retinal ganglion cell (Bovolenta and Mason, 1987), and callosal (Kalil, 1988) growth cones but differs from the findings that (1) the earliest growth cones in the fetal optic nerve have simpler profiles than later ones (Williams et al., 1986) and, conversely, (2) in Daphnia, the first retinula growth cones are more complex than later ones (Lo Presti et al., 1973). The growth cones in the present study were sampled over a narrow time window (12$18 \mathrm{hr}$ ) and subdivided into pioneers and followers. This population of fibers as a whole, has been shown to exhibit different growth properties in vitro than later developing or regenerating fibers (Grant and Tseng, 1986a, b). The possibility remains that the growth cones of these early axons are different from latergrowing axons.

\section{Retinal ganglion cells with 2 axons}

A surprising finding was that at least $5 \%$ of the retinal ganglion cells possessed more than one axon. In some cases, each axon was of a similar length and both extended into the optic tract. One might expect that axons originating from the exact same point in the retina would fasciculate or at least follow each other closely in the pathway (Scholes, 1979). This was not the case, however, since sister axons were seen to follow separate routes in the pathway, indicating that the mechanism of pathfinding occurs independently in each axon and is not under strict nuclear control. This is consistent with the finding that axonal pathfinding continues to take place in the absence of the cell soma (Harris et al., 1987) and suggests that local interactions between the growth cone and the environment direct its course. In other instances, one of the axons was short, often still within the retina, while the other axon was long, extending far into the optic tract. 
Retinal ganglion cells in the embryonic mammalian retina have been observed to occasionally extend a second axon in the opposite direction from the optic nerve head (Ramón y Cajal, 1972; Hinds and Hinds, 1974; Dann et al., 1987; Ramoa et al., $1987,1988)$ but, until the present study, have not been seen to send a second axon out of the eye into the optic nerve. It will be interesting to determine whether these double axons persist in the mature larva and, if so, where they project. One axon might terminate in the thalamic nucleus, for instance, while the other projects to the tectum.

A longstanding, as yet unresolved, issue in the developing visual system has been the observation made in several species that the number of optic axons in the nerve is significantly higher than the number of retinal ganglion cells (Lam et al., 1982; Perry et al., 1983; Provis et al., 1985; Braekevett et al., 1986). Several explanations have arisen to account for this discrepancy. It has been suggested that individual axons may branch in the developing optic nerve, although there is little evidence for this. Another possibility is that an efferent population of fibers coursing through the optic nerve to the retina may be responsible for the numerical mismatch. Efferent fibers have indeed been described (Uchiyama et al., 1988); however, their numbers are too few (30-40 in Rana catesbiana, for example) to explain the discrepancy. A further possibility in the light of the present results is that some retinal ganglion cells send out more than one axon early in development. Later on, these extra axons may be eliminated. Indeed, counts of the total numbers of ganglion cells and optic nerve fibers at different stages in Xenopus development are consistent with this possibility (Wilson, 1971) and show that retinal ganglion cell numbers are $20-30 \%$ less than optic fibcr counts throughout larval development (stages 46-52). During and after metamorphosis, however, the numbers become more or less equal, with the total number of retinal ganglion cells sometimes exceeding the number of optic fibers. Intracellular studies of older larval Xenopus did not reveal cells with more than one axon (Sakaguchi et al., 1984); however, these studies also did not detect 2 axons from single retinal ganglion cells at earlier stages. The reason for this could well be that a smaller sample size at the early stages was used.

\section{Intrinsic factors involved in dendrite genesis}

In most cases, the axons of retinal ganglion cells were seen to emerge before the dendrites began to form. This is consistent with findings in other systems (Morest, 1969; Maslim et al., 1986). It is possible that the cell body initiates dendrite formation in response to a retrograde signal being transmitted from the axon tip after it reaches a particular position in the pathway or after it invades the target. By tracing single axons into the pathway and correlating the position of the tips with the state of dendrite differentiation at the cell body, the present study has shown that dendrites begin to develop before the axon reaches the target. This supports the finding of Sakaguchi et al. (1984) that dendrites first begin to appear between stages 31-35/36. Indeed, dendrites often begin to emerge long before the axon invades the target when it is in the ventral diencephalon and sometimes even before the axon leaves the eye.

Dendrites begin as thin unbranched processes and are often tipped with knoblike varicosities. These structures bear some resemblance in their size and shape to dendritic growth cones described in the mammalian CNS (Morest, 1969; Maslim et al., 1986), but they lack filopodia. Thus, it is not clear whether they are dendritic growth cones. Around the beginning of target in- nervation, dendrites begin to branch and eventually form multiple branched arbors. The results here show that branching often begins before axons reach the tectum, although the majority of dendritic branches of the final arbor do form after tectal innervation. These results show that the initiation of dendrite formation and of branching does not depend on the axon reaching the target or a particular place in the pathway. The fact that this is not the case supports the recent finding that the dendritic arbors of retinal ganglion cells of eyes transplanted to the belly so that they do not innervate the CNS at all still form normally (Sakaguchi, 1989). A good correlation was found between the number of dendrites per ganglion cell and the position of the axon tip in the pathway. With increasing advancement along the pathway, the number of retinal ganglion cells possessing a dendrite increased as did the total number of dendrites per cell. Dendrite formation and branching correlate better with axon length than the age of the embryo. Thus, dendrite emergence and elaboration seems mostly to be an autonomous feature of individual cell maturity rather than a product of the local environment which is stage dependent.

The present results suggest the following general conclusions: (1) Optic axons navigate without passing or receiving intercellular signals via gap junctions; (2) Early growth cones advance independently in the pathway, each one being capable of responding individually to cues in the local environment; and (3) Intrinsic factors probably play a critical role in the decision to initiate dendrites and branching.

\section{References}

Argiro, V., M. B. Bunge, and M. I. Johnson (1984) Correlation between growth cone form and movement and their dependence on neuronal age. J. Neurosci. 4: 3051-3062.

Bate, C. M. (1976) Pioneer neurons in an insect embryo. Nature 260: 54-56.

Bentley, D., and M. Caudy (1983) Pioneer axons lose directed growth after selective killing of guidepost cells. Nature 304: 62-65.

Bentley, D., and H. Keshishian (1982) Pathfinding by peripheral pioneer neurons in grasshoppers. Science 218: 1082-1088.

Blackshaw, S. E., and A. E. Warner (1976) Low resistance junctions between mesoderm cells during development of trunk muscles. J. Physiol. (Lond.) 255: 209-230.

Bork, T., E. Schabtach, and P. Grant (1987) Factors guiding optic fibres in developing Xenopus retina. J. Comp. Neurol. 264: 147-158.

Bovolenta, P., and C. Mason (1987) Growth cone morphology varies with position in the developing mouse visual pathway from retina to first targets. J. Neurosci. 7: 1447-1460.

Braekevett, C. R., L. D. Beazley, S. A. Dunlop, and J. E. Darby (1986) Numbers of axons in the optic nerve and of retinal ganglion cells during development in the marsupial Setonix brachyrus. Dev. Brain Res. 25: 117-125.

Caudy, M., and D. Bentley (1986a) Pioneer growth cone morphologies reveal proximal increases in substrate affinity within leg segments of grasshopper embryos. J. Neurosci. 6: 364-379.

Caudy, M., and D. Bentley (1986b) Pioneer growth cone steering along a series of neuronal and non-neuronal cues of different affinities. $J$. Neurosci. 6: 1781-1795.

Caveney, S. (1985) The role of gap junctions in development. Annu. Rev. Physiol. 47: 319-335.

Cima, C., and P. Grant (1980) Ontogeny of the retina and optic nerve of Xenopus laevis. IV. Ultrastructural evidence of early ganglion cell differentiation. Dev. Biol. 76: 229-237.

Dann, J. F., E. H. Buhl, and L. Peichl (1987) Dendritic maturation of ganglion cells in the cat retina. Neurosci. Lett. 80: 21-26.

Dixon, J. S., and J. R. Cronly-Dillon (1972) The fine structure of the developing retina in Xenopus laevis. J. Embryol. Exp. Morphol. 28: 659-666.

Eisen, J. S., P. Z. Myers, and M. Westerfield (1986) Pathway selection by growth cones of identified motoneurones in live zebra fish embryos. Nature 320: 269-271. 
Eisen, J. S., S. H. Pike, and B. Debu (1989) The growth cones of identified motoneurons in embryonic zebrafish select appropriate pathways in the absence of specific cellular interactions. Neuron 2: 1097-1104.

Fawcett, J. W., J. S. H. Taylor, R. M. Gaze, P. Grant, and E. Hirst (1984) Fibre order in the normal Xenopus optic tract, near the chiasma. J. Embryol. Exp. Morphol. 83: 1-14.

Fujisawa, H., H. Morioka, K. Watanabe, and H. Nakamura (1976) A decay of gap junctions in association with cell differentiation of neural retina in chick embryonic development. J. Cell Sci. 22: 585-596.

Furshpan, E. J., and D. D. Potter (1968) Low resistance junctions between cells in embryos and tissue culture. Curr. Top. Dev. Biol. 3: 95-127.

Gimlich, R. L., and J. C. Gerhart (1984) Early cellular interactions promote axis formation in Xenopus laevis. Dev. Biol. 104: 117-130.

Goodman, C. S., and N. C. Spitzer (1979) Embryonic development of identified neurones: Differentiation from neuroblast to neurone. Nature 280: 208-214.

Goodman, C. S., M. Bate, and N. C. Spitzer (1981) Embryonic development of identified neurons: Origin and transformation of the $\mathrm{H}$ cell. J. Neurosci. 1: 94-102.

Grant, P., and Y. Tseng (1986a) Embryonic and regenerating Xenopus retinal fibres are intrinsically different. Dev. Biol. 114: 475-491.

Grant, P., and Y. Tseng (1986b) Clockwise neurite growth depends on developmental maturation of Xenopus retinal ganglion cells. Soc. Neurosci. Abstr. 12: 119.

Gurdon, J. B. (1977) Methods for nuclear transplantation in Amphibia. Methods Cell Biol. 16: 125-139.

Guthrie, S. C. (1984) Patterns of junctional communications in the early amphibian embryo. Nature $311: 149-151$.

Harris, W. A. (1986) Homing behaviour of axons in the embryonic vertebrate brain. Nature 320: 266-269.

Harris, W. A., C. E. Holt, T. A. Smith, and N. Gallenson (1985) Growth cones of developing retinal cells in vivo on culture surfaces and collagen matrices. J. Neurosci. Res. 13: 101-122.

Harris, W. A., C. E. Holt, and F. Bonhoeffer (1987) Retinal axons with and without their somata, growing to and arborizing in the tectum of Xenopus embryos: A time-lapse video study of single fibres in vivo. Development 101: 123-133.

Harrison, R. A. (1914) The reaction of embryonic cells to solid surfaces. J. Exp. Zool. 17: 521-544.

Hayes, B. P. (1976) The distribution of intercellular gap junctions in the developing retina and pigment epithelium of Xenopus laevis. Anat. Embryol. 150: 90-111.

Hinds, J. W., and P. L. Hinds (1974) Early ganglion cell differentiation in the mouse retina: An electron microscope analysis utilizing serial sections. Dev. Biol. 37: 381-416.

Holt, C. E. (1984) Does timing of axon outgrowth influence intitial retinotectal topography in Xenopus? J. Neurosci. 4: 1130-1152.

Holt, C. E. (1988) A single cell analysis of the early steps of retinal ganglion cell differentiation in Xenopus: From soma to axon tip. Soc. Neurosci. Abstr. 14: 674.

Holt, C. E., and W. A. Harris (1983) Order in the initial retinotectal map in Xenopus: A new technique for labelling growing nerve fibres. Nature 301: 150-152.

Holt, C. E., T. W. Bertsch, H. M. Ellis, and W. A. Harris (1988) Cellular determination in the Xenopus retina is independent of lineage and birthdate. Neuron 1: 15-26.

Hoskins, S. G., and P. Grobstein (1985) Development of the ipsilateral retinothalamic projection in the frog Xenopus laevis. J. Neurosci. 5: 920-929.

Jellies, J., C. M. Loer, and W. B. Kristan (1987) Morphological changes in Leech Retzius neurons after target contact during embryogenesis. J. Neurosci. 7: 2618-2629.

Kalil, K. (1988) Growth and guidance of axons in two pathways from the mammalian cerebral cortex. In From Message to Mind, S. S. Easter, K. F. Barald, B. H. Carlson, eds., pp. 134-149, Sinauer, Sunderland, MA.

Kapfhammer, P. J., and J. A. Raper (1987) Interactions between growth cones and neurites growing from different neural tissues in culture. $J$. Neurosci. 7: 1595-1600.

Kuwada, J. Y. (1986) Cell recognition by neuronal growth cones in a simple vertebrate embryo. Science 233: 740-746.

I am, K., A. J. Sefton, and M. R. Bennett (1982) Loss of axons from the optic nerve of the rat during early postnatal development. Dev. Brain Res. 3: $487-491$.
Letourneau, P. C. (1982) Nerve fibre growth and its regulation by extrinsic factors. In Neuronal Development, N. C. Spitzer, ed., pp. 213-254, Plenum, New York.

Levine, R. B., and Truman, J. W. (1985) Dendritic reorganization of abdominal motoneurons during metamorphosis of the moth, Manduca sexta. J. Neurosci. 5: 2424-2431.

Lo, C. W. (1980) Gap junctions in early development. Dev. Mammals 4: $39-80$.

Lo Presti, V., E. R. Macagno, and C. Levinthal (1973) Structure and development of neuronal connections in isogenic organisms: Cellular interactions in the development of the optic lamina of Daphnia. Proc. Natl. Acad. Sci. USA 70:433-437.

Lo Presti, V., E. R. Macagno, and C. Levinthal (1974) Structure and development of neuronal connections in isogenic organisms: Transient gap junctions between growing optic neurons and lamina neuroblasts. Proc. Natl. Acad. Sci. USA 71: 1098-1102.

Maslim, J., M. Webster, and J. Stone (1986) Stages in the structural differentiation of retinal ganglion cells. J. Comp. Neurol. 254: 382402.

Morest, D. K. (1969) The growth of dendrites in the mammalian brain. Z. Anat. Entwickl. Gesch. 128: 290-317.

Nieuwkoop, P. D., and J. Faber (1956) Normal Table of Xenopus laevis (Daudin), North-Holland, Amsterdam.

Perry, V. H., Z. Henderson, and R. Linden (1983) Postnatal changes in retinal ganglion cell and optic axon populations in the pigmented rat. J. Comp. Neurol. 219: 356-368.

Provis, J. M., D. Van Driel, F. A. Billson, and P. Russell (1985) Human fetal optic nerve: Overproduction and elimination of retinal axons during development. J. Comp. Neurol. 238: 92-100.

Purves, D., W. D. Snider, and J. T. Voyvodic (1988) Trophic regulation of nerve cell morphology and innervation in the autonomic nervous system. Nature $336: 123-128$.

Rager, G. H. (1980) Development of the retinal projection in the chicken. In Advances in Anatomy, Embryology and Cell Biology, Vol. 63, Springer-Verlag, Berlin.

Ramoa, A. S., G. Campbell, and C. J. Shatz (1987) Transient morphological features of identified ganglion cells in living fetal and neonatal retina. Science 237: 522-525.

Ramoa, A. S., G. Campbell, and C. J. Shatz (1988) Dendritic growth and remodeling of cat retinal ganglion cells during fetal and postnatal development. J. Neurosci. 8: 4239-4261.

Ramón y Cajal, S. (1972) The Structure of the Retina, S. A. Thorpe and M. Glickstein, eds., Thomas, Springfield, IL (English edition of work originally published in 1892).

Raper, J. A., M. J. Bastiani, and C. S. Goodman (1983) Pathfinding by neuronal growth cones in grasshopper embryos. I. Divergent choices made by the growth cones of sibling neurons. J. Neurosci. 3: 20-30.

Sakaguchi, D. S. (1989) The development of retinal ganglion cells deprived of their targets. Dev. Biol. 134: 103-111.

Sakaguchi, D. S., and R. K. Murphey (1985) Map formation in the developing Xenopus retinotectal system: An examination of ganglion cell terminal arborizations. J. Neurosci. 5: 3228-3245.

Sakaguchi, D. S., R. K. Murphey, R. K. Hunt, and R. Tompkins (1984) The development of retinal ganglion cells in a tetraploid strain of Xenopus laevis: A morphological study utilizing intracellular dye injection. J. Comp. Neurol. 224: 231-251.

Sanes, J. R. (1983) Roles of extracellular matrix in neural development. Annu. Rev. Physiol. 45: 581-600.

Scholes, J. H. (1979) Nerve fibre topography in the retinal projection to the tectum. Nature 278: 620-624.

Silver, J., and U. Rutishauser (1984) Guidance of optic axons in vivo by a preformed adhesive pathway on neuroepithelial endfeet. Dev. Biol. 106: 485-499.

Spray, D. C., A. L. Harris, and M. V. L. Bennett (1982) Control of intercellular communication via gap junctions. In Cellular Communications During Ocular Development, J. B. Sheffield and S. R. Hilfer, eds., pp. 57-84, Springer-Verlag, New York.

Stewart, W. W. (1978) Functional connections between cells as revealed by dye-coupling with a highly fluorescent naphthalimide tracer. Cell 14: 741-759.

Taghert, P. H., M. J. Bastiani, R. K. Ho, and C. S. Goodman (1982) Guidance of pioneer growth cones: Filopodial contacts and coupling revealed with an antibody to Lucifer Yellow. Dev. Biol. 94: 391-399.

Taylor, J. S. H. (1987) Fibre organization and reorganization in the retinotectal projection of Xenopus. Development 99: 393-410.

Tosney, K. W., and L. T. Landmesser (1985) Growth cone morphology 
and trajectory in the lumbosacral region of the chick embryo. J. Neurosci. 5: 2345-2358.

Uchiyama, H., T. A. Reh, and W. K. Stell (1988) Immunocytochemical and morphological evidence for a retinopetal projection in anuran amphibians. J. Comp. Neurol. 274: 48-59.

Warner, A. E., S. C. Guthrie, and N. B. Gilula (1984) Antibodies to gap-junctional protein selectively disrupt junctional communication in the early amphibian embryo. Nature 311: 127-131.

Weiss, P. (1945) Experiments on cell and axon orientation in vitro: The role of colloidal exudates in tissue organization. J. Exp. Zool. 100: 353-386.
Williams, R. W., and P. Rakic (1985) Dispersion of growing axons within the optic nerve of the embryonic monkey. Proc. Natl. Acad. Sci. USA 82: 3906-3910.

Williams, R. W., M. J. Bastiani, B. Lia, and L. M. Chalupa (1986) Growth cones, dying axons and development fluctuations in the fiber population of the cat's optic nerve. J. Comp. Physiol. 246: 32-69.

Wilson, M. A. (1971) Optic nerve fiber counts and retinal ganglion cell counts during development of Xenopus laevis (Daudin). J. Exp. Physiol. 56: 83-91. 